University of Zurich

Department of Economics

Working Paper Series

ISSN 1664-7041 (print)

ISSN 1664-705X (online)

Working Paper No. 398

\title{
The Evolution of Wages in Early Modern Normandy (1600-1850)
}

Cédric Chambru and Paul Maneuvrier-Hervieu

October 2021 


\title{
The Evolution of Wages in Early Modern Normandy (1600-1850*
}

CÉDRIC CHAMBRU ${ }^{\dagger}$ (i)

\author{
PAul MANEuVRIER-HERVIEU $\ddagger$ ๑
}

October 2021

\begin{abstract}
This paper presents new estimations of wages for Normandy between 1600 and 1850. We used a vast array of primary and secondary sources to assemble two new databases on wages and commodity prices to establish a new regional consumer price index (CPI) and twelve regional wage series. We posit that the sluggish demographic growth during the 18th century, and the resulting labour shortage, led to a convergence of wages across unskilled occupations and a relative catch-up with urban skilled construction labourers in the years preceding the French Revolution. We also provide tentative evidence suggesting that labourers in stable employment could have earned as much as their English counterparts during this period.
\end{abstract}

JEL classifications: J3, J4, I31, N33.

Keywords: Prices; Wages; Casual employment; Stable employment; Normandy.

*We thank Guillaume Daudin, Pilar Nogues-Marco, Judy Stephenson, Ulrich Woitek as well as participants at EURHO 2019, EHES 2019, ESSHC 2021, EHS 2021 meetings, and seminar audiences at the University of Caen, University of Geneva and EHESS for many helpful comments and suggestions. We are grateful to Pierre Coftier, Baptiste Étienne, Bernard Garnier, Jean-Claude Martin, Leonardo Ridolfi, the webmaster of the Désarmement Havrais, and the Société Historique de Lisieux for kindly sharing data. Merwan Sabih provided excellent research assistance. This work benefited from the financial support of the Maison de la Recherche en Sciences Humaines at the University of Caen. All errors are our own.

${ }^{\dagger}$ Cédric Chambru, Department of Economics, University of Zurich, Zürichbergstrasse 14, 8032 Zürich, Switzerland. Email: cedric.chambru@econ.uzh.ch.

$\ddagger$ Paul Maneuvrier-Hervieu, Department of Social and Political Sciences, University of Milan, Via Passione, 13, 20122 Milano, Italy. Email: paul.maneuvrier@unimi.it. 


\section{Introduction}

'Manchester is for England what Rouen is for France.'

In October 1786, Louis Ezéchias Pouchet, a textile merchant running factories producing painted canvas and silk tissues in Normandy, travelled to Manchester on behalf of the Norman Chamber of Commerce. He was to investigate the local costs of production for cotton fabric and Arkwright's machines in advance of the implementation of the Eden Treaty; which reduced customs tariffs on textile products and increased competition between France and England. On his return, he reported that producing one unit of cotton fabric was on average fifteen per cent cheaper in Manchester than in Rouen. For Pouchet, this difference did not originate in higher labour costs in Normandy. Instead, he noticed that while Norman manufacturers benefited from labour costs that were 20-5 per cent cheaper, their British counterparts had both access to cheaper raw materials and a large number of spinning jennies, giving them a significant advantage in terms of productivity. ${ }^{1}$ While the issue of wages attracted the attention of economic historians for a decade, there is, in fact little information about the dynamics of wages in Normandy during the Industrial Revolution.

In this paper, we specifically fill this gap by providing new empirical evidence on the evolution of nominal and real wages across occupations in Normandy between 1600 and 1850 . Our estimates rely on newly collected, and hitherto unexplored wage and price series covering both rural and urban areas, and including information on all groups of casual male labourers: agricultural labour; unskilled labour; skilled labour in the construction sector; marine labour; and textile labour. We also provide tentative wage-series for unskilled stable rural labourers, as well as casual female unskilled and textile labourers. One advantage of our new data set is that daily wages in the textile sector can be directly compared to daily wages in competing sectors, improving our understanding of the pattern of labour costs in the late 18th century. ${ }^{2}$

This paper focuses on Normandy, a region located to the west of Paris, which represented about ten per cent of the total French population. In the late 17th century, its capital Rouen was the second largest city in the kingdom and, with Le Havre, was on of the two main ports supplying the Parisian region and a starting point for manufactured products intended for colonial trade. Several studies have recently stressed the role played by the Norman harbour complex in French foreign trade (Daudin 2005; Maneuvrier-Hervieu 2020, Ch. 1). A century later, the value of its textile exports was three times higher than that of the ports of Bordeaux and Nantes combined, and its maritime trade accounted for nearly 20 per cent of French foreign trade. At that time, Normandy was one of the richest and most important French provinces. It had the largest industry with the highest number of factories created - in both cities and the countryside - since the start of the century (Peuchet 1799, pp. 253, 257). ${ }^{3}$

1 Biliothèque nationale de France, NUMM-48110, Observations de la Chambre du commerce de Normandie, sur le traité de commerce entre la France et l'Angleterre, pp. 16-20, 25-7, 33. https:/ / gallica.bnf.fr/ark:/12148/bpt6k481109.

2 More broadly speaking, these limited evidence can also inform the debate on the high-wage hypothesis.

3 This description, although it may seem emphatic, is nevertheless consistent with those proposed by his contemporaries. In 1765, Savary des Bruslons (1765, pp. 175-6) emphasised that Normandy region could be 
This opening to the outside world as well as the proximity of the Parisian market played a major role in the industrialisation process, with the city of Rouen as the main centre. Manufacturing and textile production was nonetheless scattered across the entire province, both in rural areas and around several provincial towns (Maneuvrier-Hervieu 2020, p. 91). The leading role of the textile industry, characterised by the rapid development of cotton spinning and weaving from the 1720s onward, was complemented by others dynamic industrial sectors like glass making, the metal industry, and the iron industry (Arnoux 1995; Vidalenc 1946), and by early agricultural specialisation intended to supply food to Paris (Abad 2002; Garnier 1999; Poncet 2019). The success of proto-industrial activities in the countryside, which employed several hundred thousand labourers, led the Parliament to implement specific regulations to reduce competition on the labour market.

During this period, Normandy had one of the highest population densities in France, but its population growth during the 18th century was only 8 per cent, while the French population grew by 20-25 per cent (Chaunu 1972, 1973). ${ }^{4}$ In Chaunu's words, Normandy was a monde plein (crowded world) that witnessed an early fertility transition with relatively late female marriage and an increasing childlessness rate across all social classes (Brée and De La Croix 2019, pp. 29-30). By 1780, Normandy had the lowest number of children per marriage in France (Dupâquier 1968, p. 68). We posit that the relative labour shortages created by the slow population growth partly contributed to the rise of wages among unskilled labourers during the second half of the 18 th century. ${ }^{5}$

There is, however, little evidence on the level of wages in Normandy for the pre-industrial period, apart from the work of Perrot (1975, pp. 780-95) on urban wages in Caen between 1740 and 1790. Allen (2015) and Geloso (2018) provide detailed information on the evolution of real wages in Paris and the region of Strasbourg, respectively, but these areas might be hardly comparable to Normandy. Similarly, Ridolfi (2019) presents new series of real wages for male labourers for French agricultural labourers, unskilled construction labourers and skilled construction labourers outside of Paris. These series, however, lack the geographical granularity to study the evolution of wages between heterogeneous regions. The question is whether these series are representative and can be used to assess the level of living standards across France. In this paper, we aim to extend Ridolfi's work by providing new regional wage series for Normandy between 1600 and 1850 .

This paper builds on and advances the historical literature on living standards and real wages in early modern Europe. In recent years, several researchers re-examined the high-

considered the main production centre and the larger exporter of textile products in France, consuming half of the cotton imported in France from the Americas and the Levant. Normandy, however, was not unique and shared some of the peculiarities with the neighbouring regions of Picardy and Flanders, which were also important centres for textile production.

4 The average population density was 13.1 households per square kilometre, roughly 55 inhabitants per square kilometre. In comparison, the population density in the Paris region was 9.6 households per square kilometre (Saugrain 1709). For a critical assessment of the survey, see Hussenet (1996).

5 That does not imply that Normandy should be considered as an high wage economy. However, one knows that labour shortages accelerated the adoption of labour-saving technology (treshing machine) in England (Caprettini et al. 2021). 
wage hypothesis, put forward by Allen $(2001,2015)$, by building new wage-series for casual unskilled labour and skilled labour in the construction sector for various European cities (e.g. Gará-Zúñiga and Lòpez Losa 2021; Ridolfi 2019; Rota and Weisdorf 2020; Stephenson 2018). Gary and Olsson (2020), Humphries and Weisdorf (2019) and Rota and Weisdorf (2021) instead address this question by building wage-series based on payments made to labourers with fixed annual contracts in the countryside. This paper contributes to the literature in several ways. First, we establish new series of nominal wages for Norman unskilled and skilled construction labourers in both rural and urban areas. We also estimate nominal wages for female and male casual agricultural labourers in rural areas, as well as wages for textile labourers and seafarers. We believe these series provide a more complete picture of the early modern economy and help identify possible discrepancies across sectors. Finally, we also provide tentative estimates of annual wages paid to stable rural female and male labourers between the late 17th and the early 19th century. Overall, preliminary estimates of the welfare ratio indicate that the long-term earnings of casual labourers were similar to those in the rest of France (Ridolfi 2019), whereas stable labourers may have been able to afford between one and one and half respectability baskets, a level similar to labourers in England (Horell et al. 2021b).

The remainder of the paper is organised as follows. Section 2 describes the sources and methodology used to assemble the wage and price series. Section 3 presents the evolution of nominal wages, and discusses the relative position of various social groups in Normandy. In Section 4, we briefly introduce preliminary estimates of real wages and relate it to the national series available for England. Section 5 concludes.

\section{Sources and methodology}

The analysis proposed in this paper is based on the construction of two new databases on wages and commodity prices in Normandy between 1601 and 1850. Overall, we collected more than 30,000 unique data points to establish twelve regional wage-series and a new regional consumer price index (CPI). We also rely on a new metrological database, which extends Allen and Murphy's work, to cover all commodity prices in metric equivalent. ${ }^{6}$ The following sections describe the sources and the methodology used to create these databases.

\subsection{Metrology and currency}

Prior to the introduction of the metric system during the French Revolution, weights and measures varied considerably by place, time and substances measured. Several French scholars conducted extensive archival research to circumvent this problem, but most of these studies focus either on regions outside Normandy, or only cover particular region within Normandy (e.g. Charbonnier 2005, 2012; Garnier 1981; Jouanne 1929). As a preliminary step, we assembled a database on metrology to provide the metric equivalent of all units of weight and measure we encounter in the data collection process. The database contains 653 unique

6 Allen and Murphy (2005) already provided such a database, but it only covers only European cities. https: //www.nuffield.ox.ac.uk/media/2143/allen-historicalweightsmeasures.pdf 
entries and gives the metric equivalent for most common goods in about 100 parishes (see Online Appendix Section A.1).

Following Allen (2001), the use of silver wage is standard in the literature to ease comparison between wage series labelled in different currencies. We decided, however, to display nominal wage series in livres tournois and/or French francs as we are mostly interested in comparison across occupations and space within Normandy. ${ }^{7}$ We based this choice on the fact that we identified hardly any relationship between changes in the silver weight of the livre tournois and variations in nominal wheat prices (Online Appendix Figure A.1 and A.12). ${ }^{8}$ In addition, Meuvret (1944, pp. 38-44) warned historians of the difficulty in converting prices labelled in livre tournois into grams of silver without knowing precisely both the date of any new Edict and its implementation across the country, especially for years when there were repeated changes, such as at the turn of the 18th century. For example, between 1709 and 1715, the silver equivalent of the livre tournois changed 10 times, and individuals and institutions often used old and new currencies of different values altogether (Jambu 2013, pp. 371-6). A last concern lies in the reliability of the annual series of silver equivalent for the livre tournois assembled by Wailly (1857). ${ }^{9}$

\subsection{Wages data}

The main challenge was to ensure good coverage of Normandy as a region and occupation across the population. In general, we considered each wage payment made to an individual labourer or group of labourers as one distinct observation. ${ }^{10}$ When possible, we indicated the name of the labourer, the name of the employer and the number of days worked in order to track individuals over time. We retrieved data on daily and annual wages from a large body of secondary sources and new archival evidence. ${ }^{11}$

To the best of our knowledge, there is no continuous series of urban wages from 1601 to 1850 available in the literature or in the archives. To circumvent this caveat, we gathered data from several sources documenting occasional repairs and/or extension of existing buildings. For instance, we compiled daily wages of masons, carpenters and other skilled construction labourers from the account records during the renovation of the University of Caen at the turn of the 17 th century. ${ }^{12}$ We also used the expense records from the Cathedral Chapter of Rouen,

7 The continuity within the series after the implementation of the franc in 1803 does not raise an issue. The franc was given a silver weight roughly equivalent to the livres tournois, which means that one franc equalled one livre tournois. The livres tournois was the fundamental currency of accounting in France prior to the 19th century. It was subdivided in 20 sols or 240 deniers.

8 Tackling the same issue, Baehrel (1961, pp. 714-6) already made similar observations half a century ago. See also Jambu (2013).

9 For more details, see Chaunu (1961, pp. 794-5), and McCusker (1997, pp. 192-3).

10 For instance, if a labourer worked weekly for an employer during one year, we collected up to 52 observations. Similarly, we considered a one time payment for 25 days of labour to a group of five washerwomen as one observation. Finally, if a scholar provided a mean wage for a set of years, e.g. 1751-4, we created one observation per year.

11 For the full list of variables included in the database, see Online Appendix Table A.2. The detailed list of sources used in this paper is available in the Online Appendix Section C.

12 Arch. dép. Calvados, D 203-362, Université de Caen, Comptabilité, 1445-1791. 
several hospital accounts and bills issued by various craftsmen to private individuals.

To establish wage series in rural areas, we used the archives produced by rural parishes, called Fabriques. These documents contain both the decisions taken by the assembly of the community of inhabitants and the sources of income and the expenditures voted by the parish for the maintenance of the church, works in the cemetery or the creation of a school. They provide information on the wages paid by the community to daily labourers for short periods of time. We also relied on the account books of several hospitals and the comptes d'exploitation from large estates and castles, such as those of Bénouville and Pontécoulant. ${ }^{13}$ For instance, in the account book for the hospital of Bayeux, we were able to track Françoise Taillepied, who worked as a laundry woman under annual contract, across several years from 1685 to $1719 .{ }^{14}$ Later on, the account book of the d'Erneville de Poligny family in Le Chesne provides detailed information on the employment of their domestic servants, such as Ménard who worked as a cook between 1778 and 1806. ${ }^{15}$ In addition, we used local monographs (e.g. Leroy 1932; Robillard de Beaurepaire 1889) and dozens of regional and local studies published in local history journals since the start of the 19th century, such as the Annuaire des cinq départements de la Normandie and the Bulletin de la Société des Antiquaires de Normandie.

We also collected data on the wages paid by the Compagnie des Indes to Norman seafarers between 1718 and 1790 as well as the wages paid to the crew reported in the Rôles de désarmenent from the port of Le Havre between 1790 and 1850. We focus on sailors and the like as well as craftsmen boarding ships. ${ }^{16}$

Overall, we collected around 18,500 unique observations for casual labour and 1,300 observations for stable employment, drawing information from 198 towns for the period 16011850 (Online Appendix Figure A.2). ${ }^{17}$ The observations are unevenly distributed over time, with the bulk corresponding to the 18th century (Online Appendix Figure A.3). The paucity of sources in the 17th century made it difficult to have extensive coverage of the period. The lack of documentation is not related to conservation issues or to the destruction of archives, but to the consequences of a series of historical events, which occurred in Normandy during this period. ${ }^{18}$ On the contrary, information on the 19th century is easily accessible and we relied

13 It is noteworthy that these accounts provided the name of labourers and their work duration for each payment. Arch. dép. Calvados, 1J 321, Compte d'exploitation du château de Bénouville, 1748-1754. Arch. dép. Calvados, F 2139-2140, Chartrier de Pontécoulant.

14 Arch. dép. Calvados, H Suppl. 722, E17 - H Suppl. 787, E82.

15 Overall, the Erneville de Poligny family employed nearly 70 different servants between 1775 and 1806, signing 280 annual contracts. Arch. dép. Calvados, 27F 18, Fonds Le Conte d'Ymouville, livre d'engagement des domestiques (1771-1814).

16 The database Mémoire des Hommes, hosted by the French Ministry of Armed Forces, provides information on all seafarers hired by the Compagnie des Indes, including their monthly salaries, occupations and home towns: https:/ / www.memoiredeshommes.sga.defense.gouv.fr. The Rôles de désarmement provide data on the monthly salaries paid to all the members of the crew for each vessel that disposed in the port of Le Havre. For more information see: http://desarmementshavrais.free.fr/.

17 We considered daily and weekly payments as remuneration for casual labour, by opposition to annual contract which were often signed on St John's between farmers and servants.

18 Among other things, the Wars of Religion, several large-scale tax riots, plague outbreaks, military battles during the Fronde, and maritime battles with England during the Nine Year's War (Foisil 1970; Logié 1951; MouchelVallon 2017; Porquet 1989). 
largely on secondary sources, which we complemented with numerous local statistical output produced by the French administration (Online Appendix Figure A.4). ${ }^{19}$ The distribution is also heavily unbalanced in terms of gender. The database includes around 1,400 wage points for women and approximately 200 wage points for children (Online Appendix Table A.4). Nevertheless, we believe that the number of observations and the spatial distribution is still sufficient to provide new reliable series of nominal wages for skilled and unskilled labourers in rural and urban areas, as well as for agricultural, textile and maritime labourers (Online Appendix Table A.4).

To calculate nominal wages by occupation by year, we first divided all observations into one of the eight categories: agricultural labour; unskilled labour; textile labour; skilled construction labour; skilled craftsman; service labour; unskilled marine labour; skilled marine craftsman (Online Appendix Table A.3). ${ }^{20}$ In many instances, employers fed labourers in addition to the cash payment. When information on the cash equivalent of such in-kind reward was not available in the source, we added the cost of one daily basket of food to the wage payment to determine overall remuneration. ${ }^{21}$ We also coded each observation as rural or urban using the location where the labourer was hired..$^{22}$ We then computed the average daily wage for each occupation in rural and urban areas for every year before aggregating the data by decade. ${ }^{23}$

\subsection{Prices data}

To collect information on prices, we relied on the same approach as for wages and used a wide range of primary and secondary sources. We first assembled and harmonised series of commodity prices previously published by historians of Normandy (Dubuc 1963; El Kordi 1970; Lemarchand 1989; Perrot 1975). These series have the shortcomings of focusing almost exclusively on urban centres and wheat prices. To address this issue, we retrieved data from new Apprécies and Mercuriales we found in the archives. These documents, kept and drawn up by the agents for each market, document the yearly or monthly prices of the main staple crops, such wheat, rye, barley and buckwheat, as well, sometimes, the prices of other commodities, such meat, poultry, butter and cider. $^{24}$ In addition, we collected data from several account

19 These sources compiled by the mayors are available in the M and Z series of the French departmental archives.

20 Agricultural labour includes all observations for which we could clearly identify the activity (e.g. tresher, shepherd). Individuals reported as daily labourers (journalier) without further details are classified as unskilled labourers.

21 Online Appendix Figure A.16 plots the evolution of the daily cost to afford the staple crops in one respectability basket between 1601 and 1805 . The daily cost of food remained stable at 2.5 sols during the entire 17th century, before steadily increasing to 5 sols in the mid-18th century. Prices then increased substantially to drive the daily cost of food to 7.5 sols on the eve of the French Revolution. For stable employment contracts, we added up the cost of one annual consumption basket, including board and lodging. It is noteworthy that, apart from hospitals and monasteries, payments in kinds were exceptional (Perrot 1975, p. 786). Indeed, we found very few cases of payment in kind, most of them for domestic servants. We did not include them in the estimates, which are therefore lower-bound estimates.

22 We set the threshold at 10,000 inhabitants at the end of the 18th century when defining a town as urban. Urban locations include the cities of Rouen $(85,000$ inhabitants), Caen $(35,000)$, Dieppe $(25,000)$, Le Havre $(20,600)$, Falaise $(14,000)$, Alençon $(13,000)$, Bayeux $(10,600)$, Lisieux $(10,100)$, and Cherbourg $(10,000)$.

23 Given the limited numbers of observations related to textile labour, we did not differentiate between urban and rural areas. Similarly, we grouped agricultural and unskilled labour for women.

24 See for instance, Arch. dép. Eure, 6 B 206, Registre des appréciations des grains pour le bailliage de Breteuil. 
books kept by noblemen, farmers or religious institutions, such as the account books from the castles of Bénouville and Pontécoulant. ${ }^{25}$ Those private sources are crucial for the construction of the price series because they indicate the price and the quantities paid by individuals for several commodities that are not included in the Apprécies and Mercuriales, such as candles. They also helped us to fill in the gaps and increase accuracy when official documents were missing or scant.

In total, the database includes around 20,000 unique observations covering about 100 towns from 1601 to 1850 . The spatial distribution of the data covers areas specialised in livestock, cereal-growing, industrial production and woodland (Online Appendix Figure A.8). Online Appendix Figure A.9 presents temporal distribution of prices data by sources. As for wages, information on the first half of the 17th century is scarcer. The peak observed in the 1780s is due to the weekly publication of several market prices in local newspapers, such as the Affiches, annonces et avis divers de la Basse-Normandie and the Journal de Rouen.

To calculate nominal prices, we first converted all commodities into their metric equivalent, and then computed an average price per unit by commodity by year. We then followed the seminal approach established by Allen (2001) and used bare-bone subsistence and respectability baskets to compute a new regional CPI, which measures the changes in the cost of living of Norman households. ${ }^{26}$ Finally, we aggregated data by decade by averaging the annual cost of each basket.

\section{Nominal wages}

This section presents the various series of Norman wages we estimated between 1600 and 1850 . We first introduce the series for skilled and unskilled labourers in rural and urban areas. Next, we depict the evolution of nominal wages for agricultural, textile and maritime labourers. Finally, we compare the annual wage for casual and stable employment for men and women in the countryside.

\subsection{Skilled and unskilled labour}

Figure 1 presents our main findings in terms of the evolution of nominal wages in rural and urban areas. Skilled construction labour includes all occupations related to the building sector, such as masons, carpenters, roofers, and painters. The series for unskilled labourers includes all labourers without any specialisation outside the agricultural, maritime, and textile sectors. It also includes all apprentices of masons, carpenters, and the like.

25 The Journal de dépense from Pontécoulant castle provides a continuous time series for several commodities and the wages paid to daily and annual labourers between 1768 and 1780 (see also Garnier 2004).

26 Following Humphries and Weisdorf (2015, p. 409), we used linear interpolation based on wheat prices to cover gaps in annual commodity prices. In Online Appendix Section B, we provide further details on the construction of the typical household basket. 
Nominal wages steadily increased from 1600 to $1850 .{ }^{27}$ These results are very much in line with the evidence presented by Ridolfi $(2019$, p. 7). As in the rest of regional France, there was little or no difference in wages between rural and urban areas for unskilled labour. Online Appendix Figure A.5 shows that nominal wages in rural Normandy were significantly below the French regional average, whereas skilled labour wages in urban Normandy were systematically 10 per cent higher than elsewhere in France. ${ }^{28}$

We further found little differences between unskilled and skilled labourer in rural areas, whereas the urban skilled premium was significant, about 50 per cent until the late 18th century. ${ }^{29}$ After 1740, this premium decreased as the nominal wages for urban skilled labour increased slower than those of the other groups. We hypothesise this phenomenon is best explained by the fact that the sluggish demographic growth resulted in a labour market shortage, improving the bargaining power of unskilled labourers (Chaunu 1972). ${ }^{30}$

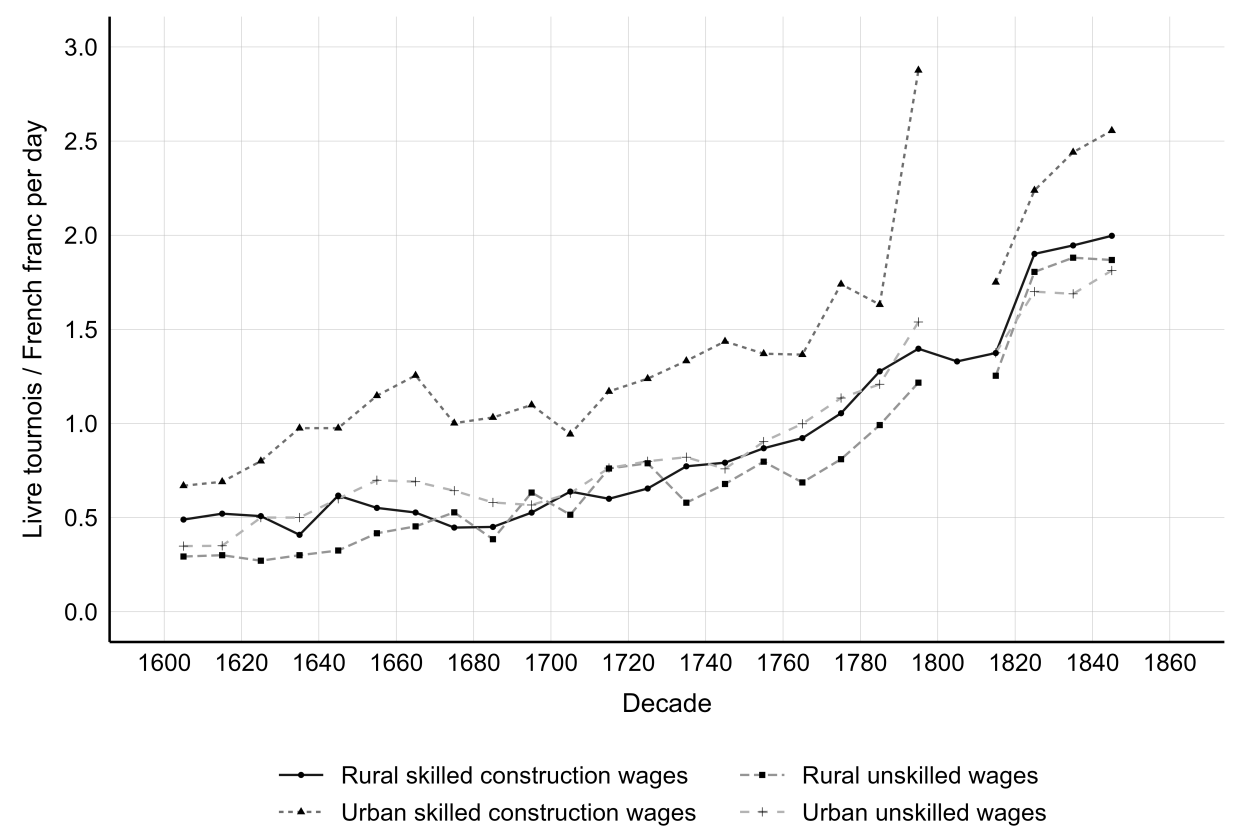

Sources: See Section 2.2 and Online Appendix Section C.

Figure 1: The nominal daily wages for skilled construction and unskilled labourers in rural and urban areas in Normandy, 1601-1850

27 The sharp increase occurring in the 1790s is to be related to the introduction of the Maximum law during the French Revolution. In 1793, as inflation was quickly rising and the assignats depreciated, the Convention decided to set the price of all the commodities and wages. They used wages and prices from 1790 and increased them by one-third and 50 per cent respectively (Margairaz 1994; Rudé and Soboul 1954).

28 Nonetheless, one caveat arises from this comparison as a significant share of the data used in the respective series overlap: about 15 per cent of the wage observations used by Ridolfi deal with Normandy, and its largest contributing city is Rouen (Ridolfi 2019, p. 10).

29 This magnitude is consistent with the size of the skill premium observed in Rome (Rota and Weisdorf 2020, pp. 945-7).

30 The presence of an urban premium for skilled labourers, but not for unskilled labourers, could originate from the fact the construction sites hired more skilled craftsmen in cities than in the countryside. The skilled gap between masons working on the cathedral of Rouen and a parish church, respectively, could have been significant. However, we lack historical evidence to document this hypothesis. 


\subsection{Agricultural labour}

In Normandy, people living in the countryside represented around 85 per cent of the population and most of them worked in the agricultural sector. Figure 2 displays the evolution of nominal wages for casual male, female, and child agricultural labourers in rural areas. These series include wage payments, made mostly by the week, to individuals working explicitly in farm-related activities such as harvesting fruits and wheat, threshing crops during winter, cutting down trees, and the like. ${ }^{31}$

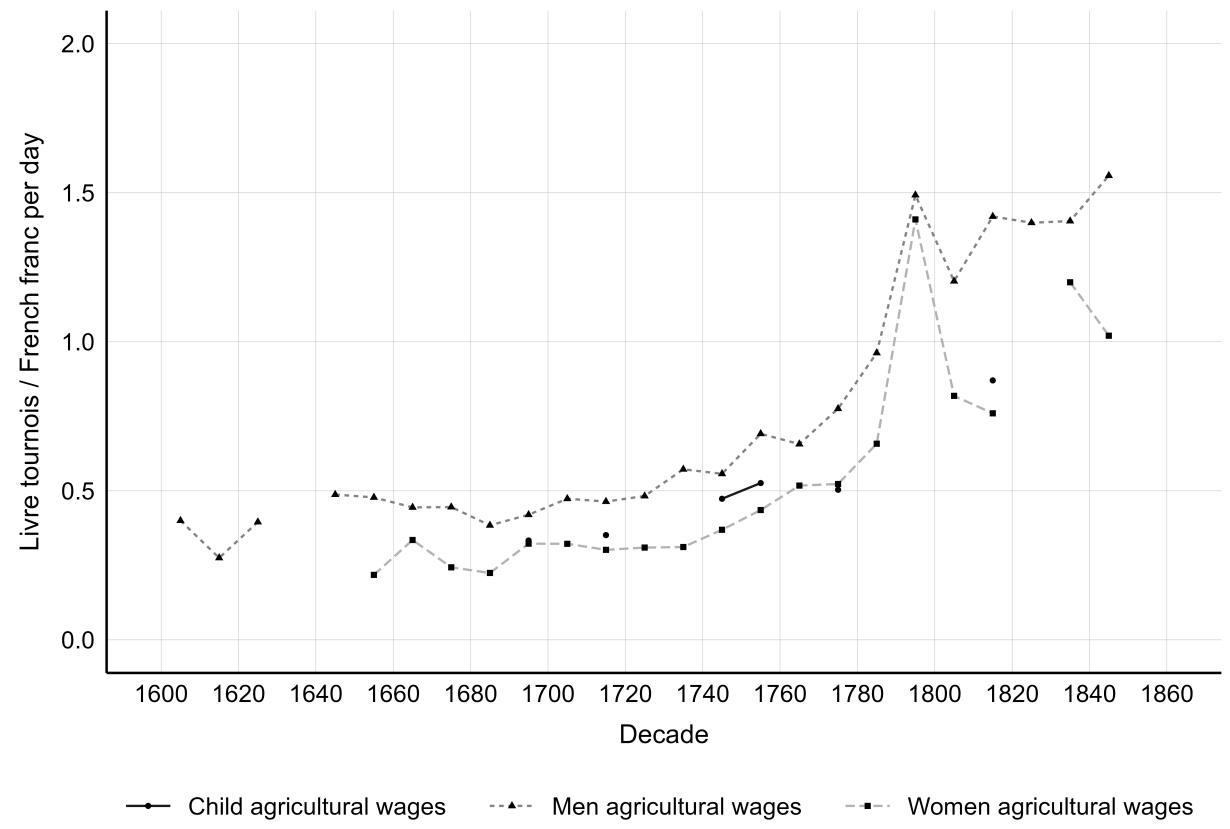

Sources: See Section 2.2 and Online Appendix Section C.

Figure 2: The nominal daily wages for casual agricultural labourers in Normandy, 1601-1850

From 1600 onwards, the nominal wages of male agricultural labourers was closely related to those of unskilled labourers in rural areas. That could arise from the fact that these (unskilled) occupations could be easily interchanged by individuals, which constrained employers to offer similar daily wages to retain their workforce. Another possibility could come from a composition effect arising from our sources and the construction of the database: all daily labourers (journaliers) in the countryside were actually agricultural labourers. While plausible, we doubt it is the main explanation as a large share of unskilled daily labourers worked on construction site. Furthermore, it should be noted that agricultural wages were on average lower than those in the textile sector. While that may seem surprising given that many textile labourers exercised their activity within a pluri-activity framework, it can be explained by the rapid expansion of the textile industry following the introduction of cotton in the countryside. In the first half of the 18th century, merchants and manufacturers (fabricants) in the textile industry offered higher wages than in the agricultural sector in order to increase production.

31 It should be noted that, by definition, very few observations concerned urban areas, which makes it impracticable to estimate wage series for agricultural labour in those area. Female and child labourers included all types of unskilled activities. 
As a result, regional authorities were forced to implement new regulations to keep agricultural labourers in the countryside during the harvest season (see Section 3.3).

\subsection{Textile labour}

Since the Middle Ages, Normandy had a privileged position in the European textile industry thanks to the quality of its woollen cloth, and its hemp and linen fabrics (Arnoux and Bottin 2001). The production, carried out in cities and in the countryside, was intended to supply the national and foreign markets. An important part of the production, known as rouenneries (literally from Rouen), was intended to supply the Spanish and French colonies. ${ }^{32}$ Therefore, when cotton appeared at the beginning of the 18th century, Normandy already had an established textile tradition. In the space of a few years, cotton spinning and weaving was in full swing. In the 1720s, the craze for cotton spinning was widespread in the countryside. Between 1717 and 1731, the production of canvas (toileries) in Rouen and its surroundings increased from 60,000 to 100,000 units (Dardel 1966, p. 316; Maneuvrier-Hervieu 2020, pp. 75-93).

The regional authorities, observing the labour shortage it created, were then concerned about its consequences for agriculture, stressing its effects on wages. After sending several unsuccessful requests to the king asking him to ban spinning in the countryside, the Parlement de Rouen implemented new regulations to limit the increase in wages and the lack of labourers in the agricultural sector during the harvest. ${ }^{33}$ In 1723, the Parliament decree forbade masters and manufacturers in the towns of Rouen and Darnétal from employing countryside labourers between 1 July and 15 September. ${ }^{34}$ That did not, however, prevent the cotton industry from growing. At the end of the 18th century, several contemporary accounts estimated that it now enabled more than 180,000 individuals to ensure their daily subsistence. ${ }^{35}$ Becchia (2000, p. 440) reports that, in the 1780s, manufacturers in Elbeuf were prompt to adopt mechanisation to alleviate their difficulties to find labourers.

The paucity of sources and the practice of paying wages by the piece make it difficult to collect extensive information on wages in the textile sector from 1601 onwards. Nevertheless, we managed to gather few hundreds observation of daily wage payments made to men, women, and children between 1740 and 1850. We only included observations of unskilled and low-skilled labourers in the textile industry, such as spinners, weavers, and lacemakers. Skilled labourers, such as tailors, upholsterers, hatters, quilters, and embroiderers were excluded from the wage series.

32 In the 16th century, Norman textile production was exported through Europe as well as to Morocco and West Africa (Bottin 1995; Maneuvrier 2016).

33 A mémoire (report) written by the municipality of Rouen in 1722 indicates that the development of cotton spinning led to an increase in agricultural wages since: 'the daily labourers, the barn treshers, paid 7, 8, 9 and 10 sols today, demand 20, 25 and even 30 sols, plus food'. Arch. nat. G7 503-505, quoted by Sion (1909).

34 Recueil des Edits et declarations, lettres patentes, arrests et reglemens du Roy, Registré en la Cour du Parlement de Normandie, depuis l'Année 1718 jusqu'en 1726. Rouen : Lallemant, 1755. The edict published on 17 July 1723 is available at: https://gallica.bnf.fr/ark:/12148/bpt6k96169631/f507.item.

35 Arch. nat., F 12 650, Inspecteurs des manufactures : mémoires. 1704-1789. 


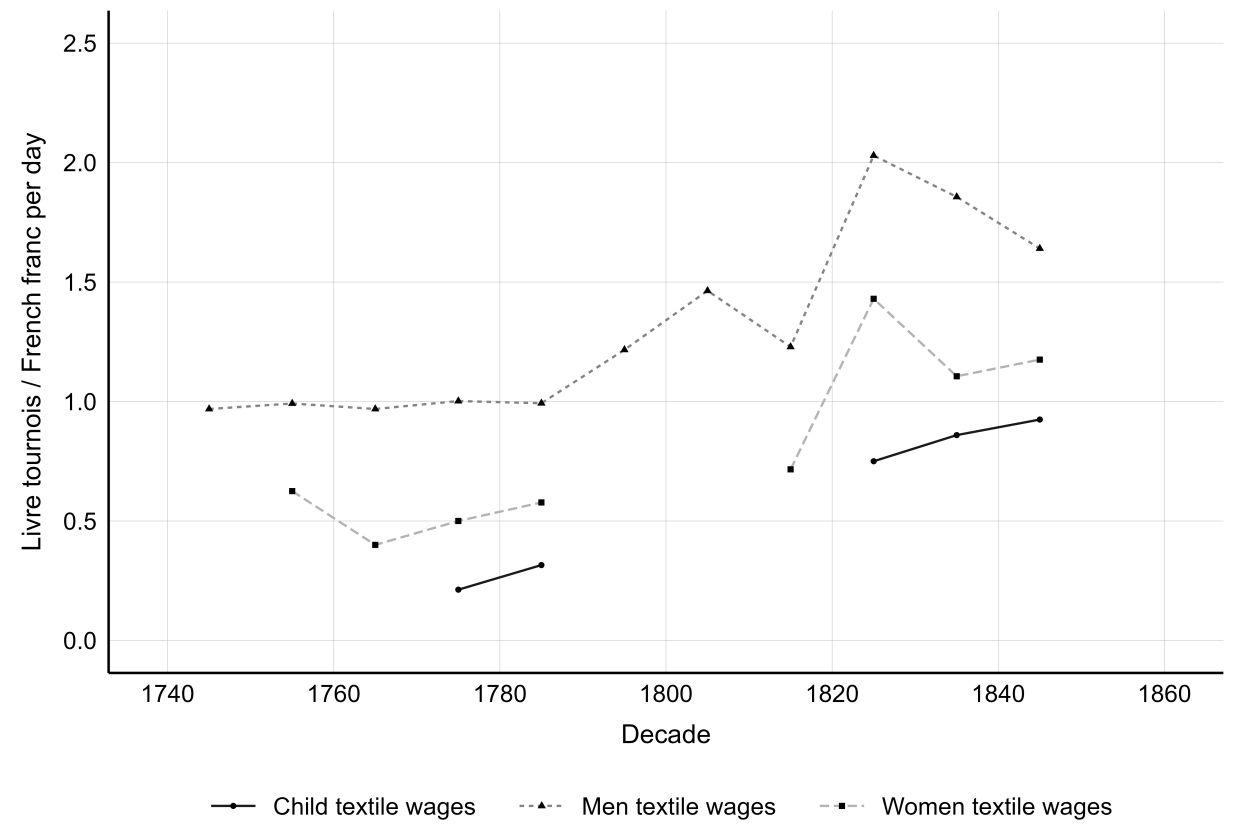

Sources: See Section 2.2 and Online Appendix Section C.

Figure 3: The nominal daily wages for textile labourers in Normandy, 1601-1850

Figure 3 shows the evolution of nominal wages in the textile industry between 1740 and 1850. In the second half of the 18th century, wages were slightly higher in the textile industry than the agricultural sector for both sexes. ${ }^{36}$ We posit the high demand for labour in the textile industry and the labour shortage in Normandy could be a plausible explanation for this gap between agricultural and textile wages. The labour regulations implemented by the Parliament during the harvests were necessary to prevent increases in labour costs and labour shortages in the agricultural sector, which could potentially endanger the food supply in the region.

\subsection{Maritime labour}

With over $600 \mathrm{~km}$ of coastlines, maritime activities such as fishing, trading and long-distance shipping were essential for many people living in Normandy. Using the archival records of the Compagnie des Indes and the Rôles de Désarmement, we collected around 7,300 observations to document the evolution of wages in the maritime sector for both unskilled labourers and skilled craftsmen. It should be noted that we did not include all the wages paid to officers or those in the service sector, such as chaplains and accountants. The skilled craftsmen category includes carpenters, caulkers, coopers, and blacksmiths. The unskilled category corresponds to the wages paid to ordinary seamen, servants, and/or apprentice sailors. ${ }^{37}$

Figure 4 displays the evolution of the nominal wages for skilled maritime craftsmen and unskilled labourers. As for the other sectors, the nominal wages increased during the 18th

\footnotetext{
${ }^{36}$ In textile as in agriculture, we find the gender wage gap to be approximately 50 per cent, which is consistent with the wage gap observed by Humphries and Weisdorf (2015, pp. 427-8) in 18th-Century England.

37 Contrary to most of the other labourers, maritime labourers worked 30 days per month during their contract and were fed on-board.
} 
century. Maritime wages for skilled and unskilled labourers were slightly higher than those in the agricultural and construction sectors. Most of the maritime wages correspond to salaries paid for long-term expeditions lasting several months, and such differences can be explained by a risk premium paid to the labourers for long-distance shipping. ${ }^{38}$ This new wage series for maritime labour confirms that the rise in nominal wages previously observed in the literature for wages in the construction sector also occurred in other sectors of the economy.

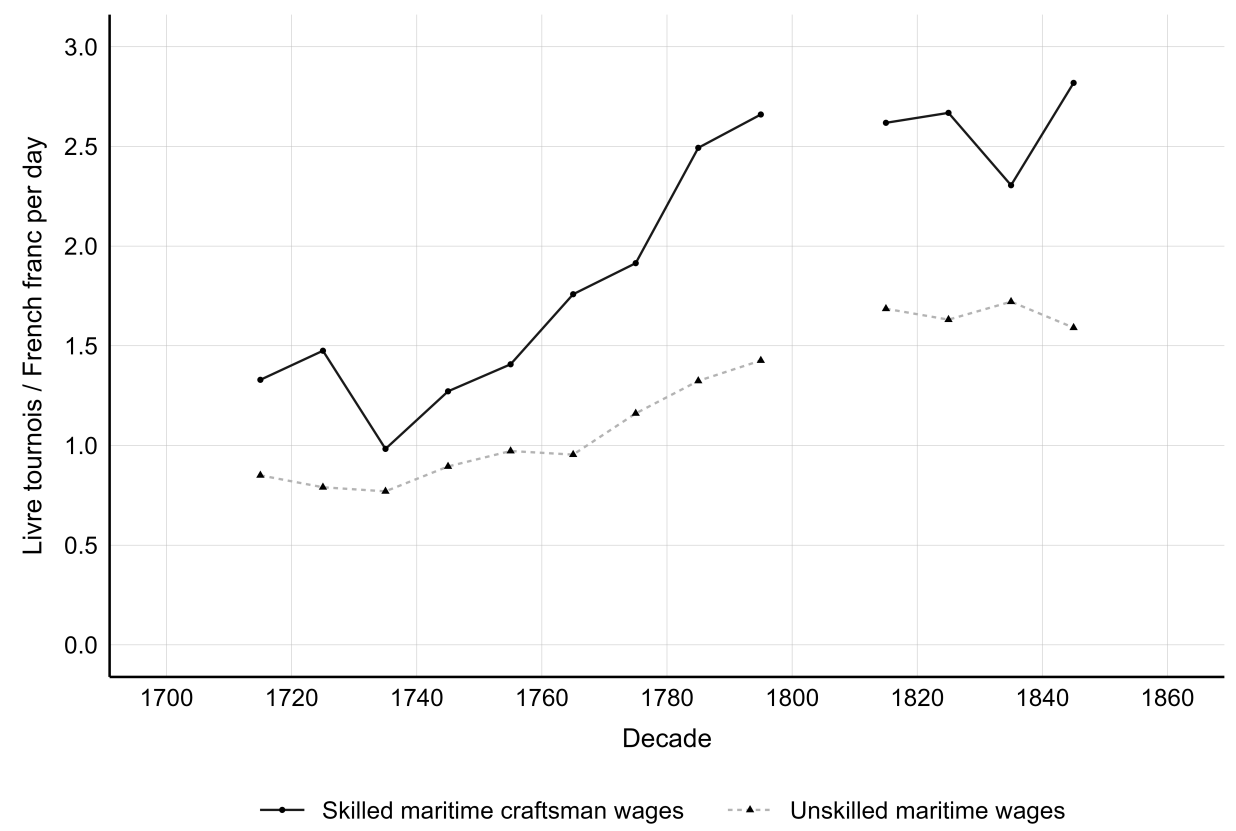

Notes: The figure shows the nominal day rates for maritime labourers. It should be noted that they were paid on a monthly basis and fed on-board. We divided their monthly wage by 30 to estimate the daily rate. Sources: See Section 2.2 and Online Appendix Section C.

Figure 4: The nominal daily wages for maritime labourers in Normandy, 1601-1850

\subsection{Stable employment in rural areas}

Stable employment with fixed annual contracts in the countryside has been at the centre of several recent research projects re-examining the high-wage hypothesis (Humphries and Weisdorf 2019; Rota and Weisdorf 2021). ${ }^{39}$ To extend our previous results, we collected data to document the evolution of nominal wages for stable employment in rural areas. Fragmentary evidence for both sexes is presented in Figure $5 .{ }^{40}$

38 Haudrère (2014, pp. 169-71) reports that, during the 18th century, the on-board mortality rate was about 15 per cent for maritime voyages between Europe and the Indian Ocean. It should be noted that seamen also often worked in various sectors when they were on land, which means that their overall remuneration was composed of a mixture of maritime and land wages (Sauzeau 2013).

39 See Humphries and Weisdorf (2015, pp. 412-7) for an in-depth discussion on the difficulties arising from estimating annual wages from stable contracts.

40 Due to data limitations, we used stable employment contract for both agricultural and unskilled labour (e.g. cook, laundry woman and the like). We further relied on observations from urban areas, mostly from the Bayeux hospital at the turn of the 18th century, for female labourers. In Section 3.1, we showed that there were few differences between male daily unskilled wages in rural and urban areas. Therefore, we believe the bias introduced by including urban female wages is limited. 
The long-term trend is similar to that of casual employment in the agricultural sector, with a significant increase from 1750 onward before a relative stabilisation in the 19th century. It is noteworthy that there is little difference between annual male and female wages between the 17th and the late 18th century. For instance, a male domestic labourer employed as a nursing assistant at the Bayeux hospital in 1776 earned fifty livres tournois per year, the same as the laundry woman. ${ }^{41}$ In England, Humphries and Weisdorf (2015, pp. 428-9) shows that the gender wage gaps for casual labourers remained fairly stable between the mid-17th and the mid-18th century before widening in the 1760s with 'the onset of competition from spinning machinery and the catastrophic fall in spinner's potential earnings'. The dynamics seems similar in Normandy, but started few decades later. In 1789, labourers in Caen complained that the English spinning machines 'ha[d] paralysed the labourer's arm and dealt a deathblow to the industry of the women spinners' (Jarrige 2013, pp. 17-22). Fifteen years later, a group of women in Guibray threatened to destroy a spinning machine to protest against the low wages decided by the mill owners. Given the large number of women spinners at the turn of the 19th century, a labour market shock like that could easily have impacted women's wages across sectors, explaining the observed decline in nominal wages for stable employment in the first decades of the 19th century.

Before that, women's remuneration from stable employment was quite on par with that of their unskilled male counterparts, which is consistent with previous findings for England (Humphries and Weisdorf 2015, p. 429). Aware of the situation in the labour market in Elbeuf and its neighbouring area, spinners were demanding increasingly better working conditions and higher wages to manufacturers at the turn of the 1780s (Becchia 2000, p. 440). The chronic labour shortage faced by employers during the second half of the 18th century possibly drove them to increase women's wage rates to attract and/or retain female labourers. ${ }^{42}$

\section{Real wages}

In this section, we provide tentative evidence on the evolution of individual real wages in early modern Normandy. We first present a new regional CPI for Normandy and discuss its main trends. We then provide annual welfare ratios for female and male casual agricultural labourers in rural areas. We focused on rural areas for this exercise because it was where the vast majority of the population used to live. We used only wage series for agricultural labourers as they are fairly representative of other unskilled occupations. All estimates are based on the assumption that individuals worked 250 days per year. ${ }^{43}$

41 Arch. dép. Calvados, H Suppl. 895, E190, Hospices de Bayeux.

42 A conclusion that should, nonetheless, be interpreted with cautious given the limited number of data points for these two groups.

43 Providing detailed estimates on the evolution of living standards of Norman households is beyond the scope of the paper. Such estimates require additional fine-grained data on the composition of households, their saving behaviour, and the amount of labour inputs. In addition, daily wage rates further require strong assumptions on the number of days worked to infer annual earnings (Horell et al. 2021a,b). Preliminary evidence from account books indicated that working 275 to 300 days per year was not uncommon in Normandy, which is line with the graphical evidence shown in Online Appendix Figure A.6. The figure displays the number of days of casual employment that a man would have had to work to earn an income equivalent to those employed under a stable 


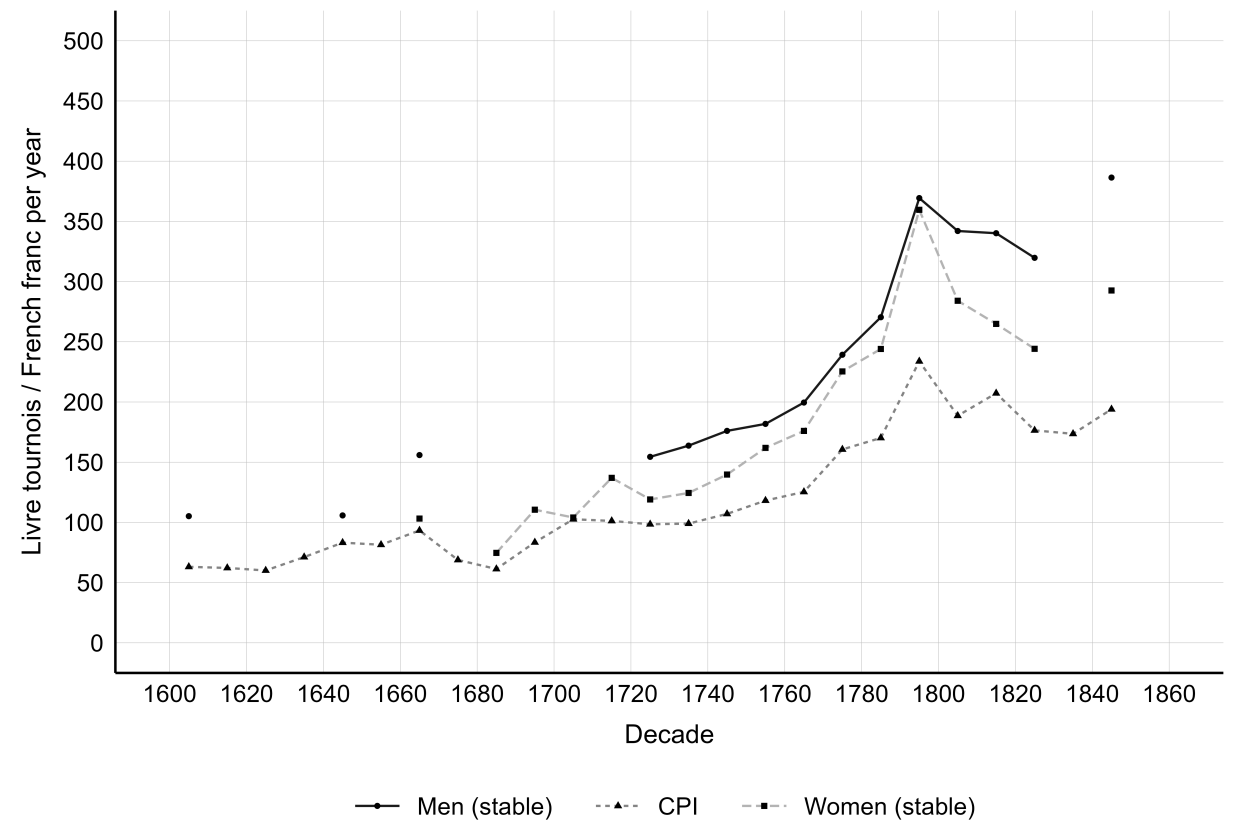

Notes: To account for in-kind payment, we added to the annual payment the cost of one annual consumption basket, including board and lodging. Annual, rather than daily, earnings are displayed to avoid making an assumption on the number of days worked per year.

Sources: See Section 2.2 and Online Appendix Section C.

Figure 5: The nominal annual earnings for stable employment in rural areas in Normandy, $1601-1850$

\subsection{The consumer price index}

Online Appendix Figure A.13 displays the annual evolution of the CPI in Normandy for the respectability basket and the bare bones basket between 1600 and 1850 . Two major trends can be identified in this new CPI: a period of relative stability until the mid-18th century, and a steady rise in the second half the 18th century which culminated in the Maximum during the French Revolution. ${ }^{44}$ Beyond these trends, the five peaks we observed correspond to well-known episodes of subsistence crises in Normandy. The first one is the so-called crise de l'avènement which broke out at the beginning of the reign of Louis XIV after two successive bad harvests (Bondois 1924). The second corresponds to the Grand Hyver that struck all countries in Europe in 1709 (Alfani and Ó Gráda 2017). Less well known is the peak occurring in 17945 during the French Revolution. It was the result of poor harvests and a harsh winter in Normandy, aggravated by the numerous grain requisitions made by the government to supply the revolutionary armies. In the city of Rouen, the situation sparked a severe famine that led to a doubling of mortality (Cobb 1956). Finally, the last two peaks correspond to the 1812 crisis, which was particularly severe in Normandy, followed by the year without a summer in 1817

contract. Until the French Revolution, casual male labourers had always had to work between 275 and 300 days to keep up, which may contradict the recent findings from Ridolfi (2021, pp. 137-9). Relaxing the assumption on the 250 days of work per year would mechanically increase the welfare ratio. For instance, moving from 250 to 275 days would increase the welfare ration by 10 per cent over the entire period.

44 In Online Appendix Figure A.15, we shows that the CPI trend is similar to those observed in England, except for the revolutionary period. 
following the eruption of the Tambora volcano, and the crisis that led to the 1848 Revolution.

\subsection{Norman real wages}

Figure 6 charts the welfare ratios of various individual family members employed as casual labourers under the assumption of 250 days of worked per year. Recent evidence suggests that the welfare ratio of an English household composed of unskilled labourers remained relatively stable between the early 17th century and 1840. The average English family could afford between 1.1 and 1.4 household respectability baskets (Horell et al. 2021b, p. 117). The trends look quite similar in Normandy. ${ }^{45}$ A woman working in casual agricultural labour could afford about one respectability basket between 1650 and the late 18th century, whereas her husband would be slightly better off with approximately 1.3 respectability baskets. The increase in nominal wages observed at the turn of the 19th century (Figure 2) was higher than the changes in the costs of living, plausibly resulting in an overall improvement of the standards of living from 1800 onwards.

In Figure 1, we showed that the levels and trends in nominal wages across unskilled occupations were similar in Normandy. That means that even in a framework in which household members would switch from one unskilled occupation to another, differences in the standards of living were likely to be small. These preliminary estimates require further research into the evolution of working time, and the changes in composition and activities of households before drawing any conclusions on the role of wages in the Industrial Revolution in Normandy.

\section{Conclusion}

In this paper, we presented two new databases on prices and wages in early modern Normandy to document the evolution of wages across various sets of occupations in rural and urban areas. While the wage series do not significantly depart from the series for regional France established by Ridolfi (2019), they constitute the first in-depth investigation at regional level allowing for a better understanding of the factors driving the observed trends. ${ }^{46}$ In particular, we posit that the sluggish demographic growth during the 18th century, and the resulting labour shortage, led to a convergence of wages across unskilled occupations and a relative catch-up with urban skilled construction labourers.

One main caveat of this paper is that we presented little information on the length of the working year between 1601 and 1850. That makes the estimation of welfare ratios hazardous and comparisons between casual and stable employment difficult. ${ }^{47}$ Besides, better information on the composition of Norman households and on labour-force participation

45 Online Appendix Figure A.7 displays the welfare ratios for stable labourers and shows similar trends.

46 That some of our data sources are redundant with Ridolfi's ones for regional France can partially explain the overlap.

47 For instance, it is possible to attribute a gap in the annual earnings between casual and stable labourers to either a job insecurity premium or a wrong assumption on the length of the work year. 


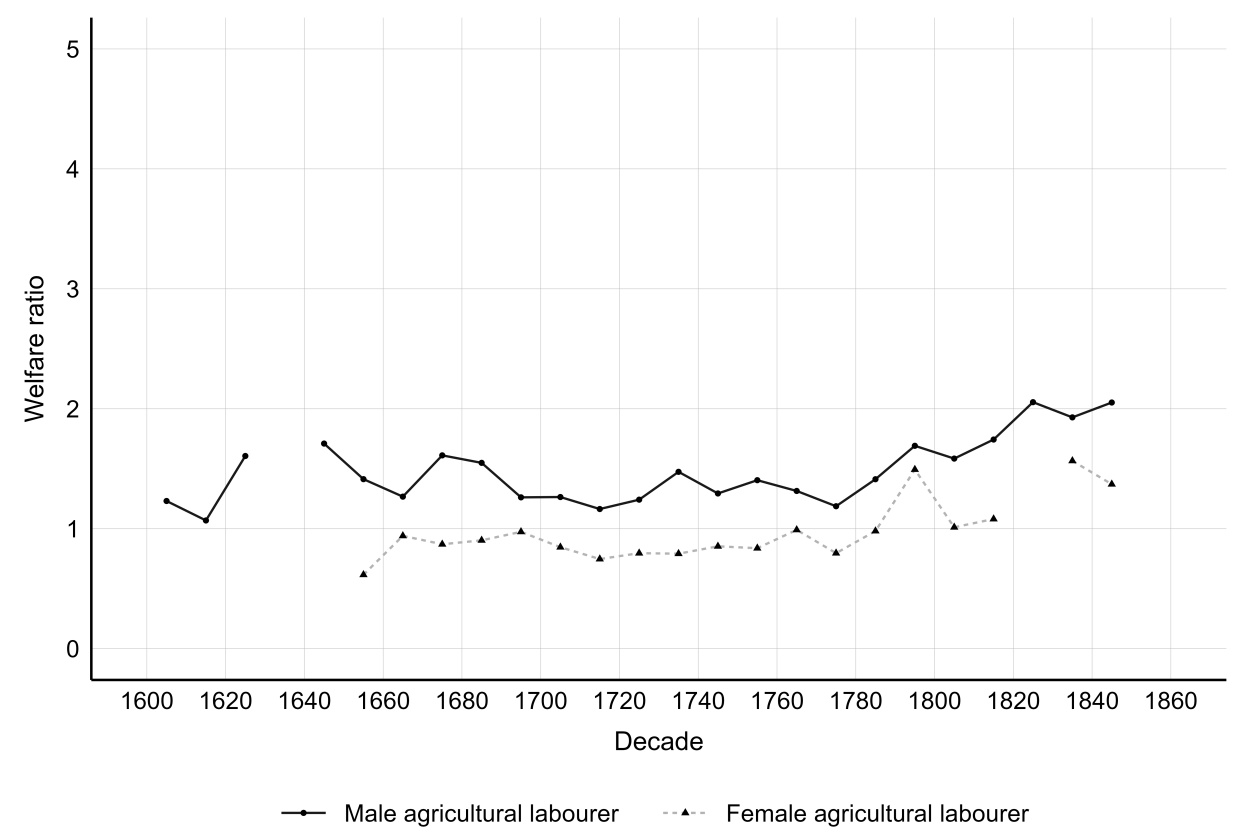

Notes: The daily payments are turned into annual earnings on the assumption of a five-day work week (totalling 250 working days per year). The welfare ratio is obtained by dividing the total annual earnings by the cost of one respectability basket.

Sources: See Sections 2.2 and 2.3 and Online Appendix Section C.

Figure 6: The welfare ratio for daily agricultural labourers in Normandy, 1601-1850

rates would be necessary to provide a detailed picture of the trends in standards of living in Normandy. Nevertheless, we think that this paper contributes to the existing literature in at least three ways.

First, we established series of nominal wages for unskilled and skilled construction labourers in both rural and urban areas. We further provided series of nominal wages for female and male casual agricultural labourers in rural areas, allowing for comparison between activities across spaces and also among them within space. We found that the earnings of unskilled labourers were relatively stable across activities and space, suggesting that unskilled urban labourers were not more productive than their counterparts in the countryside. However, we also documented a significant skilled premium in urban areas, which was roughly similar to those in other large European cities. In the long run, nominal wages remained quite stable until the mid-18th century before steadily increasing. Urban wages in the construction sector, however, increased at a slower pace indicating the potential existence of a relative urban downturn from 1750 onward. Additional preliminary evidence suggests that the real earnings of the Norman population in the countryside remained roughly stable until the French Revolution - under the assumption of a fixed 250-day work year.

A second important contribution is the creation of four additional wage series for female and male textile labourers, and unskilled and skilled labourers in the maritime sector. To the best of our knowledge, these series are the first of their kind for early modern France and allow further comparison to be drawn across occupation and space. The skilled premium in the maritime sector is fairly consistent with the premium observed in urban areas. It is noteworthy, however, 
that both unskilled and skilled seafarers benefited from a risk premium, plausibly to cover the high risk of death on ships. Fragmentary evidence on the evolution of textile wages for both female and male labourers suggests that earnings were slightly higher in this sector than in the agricultural sector. As the result, the dearth of labourers forced farmers to increase wages for casual labourers, and the Parliament to regulate hirings in the textile sector to ensure that harvests could be completed.

Third, we also provided a new series of annual wages paid to stable rural female and male labourers between the late 17th and the early 19th century. We showed that there was little difference between annual male and female earnings until the 18th century. Following Humphries and Weisdorf (2015), we hypothesise that the high demand for labour in the textile sector stimulated female wages until the introduction of the spinning jenny. After the introduction of mechanisation in the 1780s, we observed an increase in the wage gap between female and male stable labourers as a result of the decline in demand for spinners. 


\section{References}

Abad, Reynald (2002). Le grand marché. L'approvisionnement alimentaire de Paris sous l'Ancien Régime. Paris: Fayard, p. 1030.

Alfani, Guido and Cormac Ó Gráda, eds. (2017). Famine in European History. Cambridge: Cambridge University Press, p. 326. DOI: 10.1017/9781316841235.

Allen, Robert C. (2001). 'The Great Divergence in European Wages and Prices from the Middle Ages to the First World War'. Explorations in Economic History 38.4, pp. 41-47. DOI: 10.1006/ exeh.2001.0775.

- (2015). 'The High Wage Economy and the Industrial Revolution: A Restatement'. The Economic History Review 68.s1, pp. 8-38. DOI: 10.1111/ehr.12079.

Allen, Robert C. and Tommy E. Murphy (2005). 'Just before the Metre, the Gram, the Litre: Building a Rosetta Stone of Weights and Measures in the Early Modern World'.

Arnoux, Mathieu (1995). Mineurs, ferons et maîtres de forge : étude sur la production du fer dans la Normandie du Moyen Âge, XI $-X V^{e}$ siècles. Paris: Éditions du CTHS, p. 646.

Arnoux, Mathieu and Jacques Bottin (2001). 'Autour de Rouen et Paris : modalités d'intégration $\mathrm{d}^{\prime}$ un espace drapier (XIII ${ }^{\mathrm{e}}-\mathrm{XVI}^{\mathrm{e}}$ siècles)'. Revue d'histoire moderne et contemporaine 48.2, pp. 162-191. DOI: $10.3917 /$ rhmc.482.0162.

Baehrel, René (1961). 'Prix, superficies, statistique, croissances'. Annales. Économies, Sociétés, Civilisations 16.4, pp. 699-722. DOI: 10.3406/ahess.1961.421722.

Becchia, Alain (2000). La draperie d'Elbeuf des origines à 1870. Rouen: Publications de l'Université de Rouen, p. 869.

Bondois, Paul M. (1924). 'La misère sous Louis XIV. La disette de 1662'. Revue d'histoire économique et sociale 12.1, pp. 53-118.

Bottin, Jacques (1995). ‘Réflexions sur un modèle de croissance commerciale : Saint-Malo et ses négociants à l'époque de Louis XIV'. Revue d'histoire moderne et contemporaine 42.1, pp. 142150. DOI: $10.3406 /$ rhmc.1995.1761.

Brée, Sandra and David De La Croix (2019). 'Key Forces behind the Decline of Fertility: Lessons from Childlessness in Rouen before the Industrial Revolution'. Cliometrica 13, pp. 25-54. DOI: $10.1007 /$ s11698-017-0166-9.

Caprettini, Bruno, Alex Trew and Hans-Joachin Voth (2021). 'Fighting for Growth. WarInduced Labor Shortages and Technology Adoption during the British Industrial Revolution'. Unpublished manuscript.

Charbonnier, Pierre (2005). Les anciennes mesures locales du Centre-Est, d'après les tables de conversion. Clermont-Ferrand: Presses universitaires Blaise Pascal, p. 408.

- (2012). Les anciennes mesures du Centre historique de la France, d'après les tables de conversion. Paris: Éditions du CTHS, p. 552.

Chaunu, Pierre (1961). 'Sur le front de l'histoire des prix au XVI ${ }^{\mathrm{e}}$ siècle : de la mercuriale de Paris au port d'Anvers'. Annales. Économies, Sociétés, Civilisations 16.4, pp. 791-803. DOI: 10.3406/ahess.1961.421733.

- (1972). 'Malthusianisme démographique et malthusianisme économique : l'échec économique de la Normandie à l'époque du démarrage'. Annales de Normandie 27.1, pp. 1-19. DOI: 10. 3406/ahess.1972.422477. 
Chaunu, Pierre (1973). 'Réflexions sur la démographi normande'. Annales de démographie historique, pp. 97-117. DOI: 10.3406/adh.1973.1134.

Cobb, Richard Charles (1956). 'Disette et mortalité. La crise de l'an III et de l'an IV à Rouen'. Annales de Normandie 6.3-4, pp. 267-291. DOI: 10.3406/annor.1956.4320.

Dardel, Pierre (1966). Commerce, industrie et navigation à Rouen et au Havre au XVIII siècle. Rivalité croissante entre ces deux ports. La conjoncture. Rouen: Société libre d'émulation de Seine-Maritime, p. 456.

Daudin, Guillaume (2005). Commerce et prospérité : La France au XVIII siècle. Paris: Presses Paris Sorbonne, p. 588.

Dubuc, André (1963). 'L'appréciation des redevance en nature dans le baillage principal de Rouen (1694-1790)'. In: Actes du 87e Congrès national des sociétés savantes (Poitiers, 1962). Section d'histoire moderne et contemporaine. Paris: Imprimerie Nationale, pp. 813-847.

Dupâquier, Jacques (1968). 'Sur la population française au XVII et au XVIII ${ }^{\mathrm{e}}$ siècle'. Revue historique 239.1, pp. 43-79.

El Kordi, Mohamed (1970). Bayeux aux XVII et XVIII siècles. Contribution à l'histoire urbaine de la France. Paris: E.P.H.E., VIe section Sciences Économiques et Sociales, p. 372.

Foisil, Madeleine (1970). La révolte des nu-pieds et les révoltes normandes de 1639. Paris: Presses Universitaires de France, p. 368.

Gará-Zúñiga, Mario and Ernesto Lòpez Losa (2021). 'Skills and Human Capital in EighteenthCentury Spain: Wages and Working Lives in the Construction of the Royal Palace of Madrid (1737--1805)'. The Economic History Review 0.0, pp. 1-30. DOI: 10.1257/app.20190416.

Garnier, Bernard (1999). 'Des boeufs pour Paris : Commercialisation et élevage en BasseNormandie (1700-1900)'. Annales de Bretagne et des pays de l'Ouest 106.1, pp. 101-120. DOI: $10.3406 /$ abpo.1999.4017.

- (2004). 'Aspects matériels de la vie à Pontécoulant au XVIII siècle'. Annales de Normandie 54.2-3, pp. 115-166. DOI: 10.3406/annor.2004.1484.

- (1981). 'Sur la métrologie des grains en Basse Normandie au XVIII siècle'. In: Les anciens systèmes de mesures : projet d'enquête métrologique, Actes de la Table Ronde du 17 octobre 1981 (Paris, 17th Oct. 1981). Paris: Éditions du CNRS, pp. 55-67.

Gary, Kathryn E. and Mats Olsson (2020). 'Men at Work. Wages and Industriousness in Southern Sweden 1500-1850'. Scandinavian Economic History Review 68.2, pp. 112-128. DOI: 10.1080/03585522.2019.1704859.

Geloso, Vincent (2018). 'Were Wages That Low? Real Wages in the Strasbourg Region Before 1775'. The Journal of Interdisciplinary History 48.2, pp. 511-522. DOI: 10.1093/restud/rdv019.

Haudrère, Philippe (2014). 'Heurs et malheurs des voyages maritimes sur la route des Indes orientales au XVIII siècle'. Annales de Bretagne et des pays de l'Ouest 121.3, pp. 165-175. DOI: $10.4000 /$ abpo. 2853.

Horell, Sara, Jane Humphries and Jacob Weisdorf (2021a). 'Beyond the male breadwinner: Lifecycle living standards of intact and disrupted English working families, 1260-1850'. The Economic History Review, pp. 1-31. DOI: 10.1111/ehr.13105.

- (2021b). 'Family Standards of Living Over the Long Run, England 1280-1850'. Past $\mathcal{E}$ Present 250.1, pp. 87-134. DOI: 10.1093/pastj/gtaa005. 
Humphries, Jane and Jacob Weisdorf (2015). 'The Wages of Women in England, 1260-1850'. The Journal of Economic History 75.2, pp. 405-447. DOI: 10.1017/S0022050715000662.

- (2019). 'Unreal Wages? Real Income and Economic Growth in England, 1260-1850'. The Economic Journal 129, pp. 2867-2887. DOI: 10.1093/ej/uez017.

Hussenet, Jacques (1996). 'Les dénombrements Saugrain. Genèse et hypothèses'. Annales de démographie historique 1, pp. 295-312. DOI: 10.3406/adh.1996.1923.

Jambu, Jérôme (2013). Tant d'or que d'argent : la monnaie en Basse Normandie à l'époque moderne (XVI - XVIII ${ }^{e}$ siècle). Rennes: Presses Universitaires de Rennes, p. 640.

Jarrige, François (2013). 'Gender and Machine-breaking: Violence and Mechanization at the Dawn of the Industrial Age (England and France 1750-1850)'. Clio. Women, Gender, History 38.2, pp. 17-40. DOI: 10.4000/clio.11558.

Jouanne, René (1929). ‘Comparaison entre les mesures anciennes et les mesures nouvelles du département'. Bulletin du comité départemental de l'Orne 22.2, pp. 42-52.

Lemarchand, Guy (1989). La fin du féodalisme dans le pays de Caux. Conjoncture économique et démographique et structure sociale dans une région de grande culture : de la crise du XVIIe siècle à la stabilisation de la Révolution (1640-1795). Paris: Éditions du CTHS, p. 661.

Leroy, Henry (1932). 'Le livre de raison de François Tessier de la Roche'. Bulletin de la Société libre d'émulation du commerce et de l'industrie de la Seine-Inférieure Année 1931, pp. 159-174.

Logié, Paul (1951). La Fronde en Normandie. 3 vols. Amiens: Pauteur.

Maneuvrier, Christophe (2016). ‘Paulmier de Gonneville et le Portugal : un navigateur normand dans la première mondialisation'. Revista de História da Sociedade e da Cultura 16.1, pp. 95-109. DOI: 10.14195/1645-2259_16_5.

Maneuvrier-Hervieu, Paul (2020). 'La Normandie dans l'économie atlantique au $18^{\mathrm{e}}$ siècle. Production, commerce et crises'. PhD Thesis. Université de Caen-Normandie, p. 675.

Margairaz, Dominique (1994). 'Le maximum, politique économique ou politique sociale ?' In: Robespierre. De la Nation artésienne à la République et aux Nations. Ed. by Hervé Leuwers, Jean-Pierre Hirsch and Gilles Deregnaucourt. Lille: Publications de l'Institut de recherches historiques du Septentrion, pp. 263-278.

McCusker, John J. (1997). Essays in the Economic History of the Atlantic World. London: Routledge, p. 284.

Meuvret, Jean (1944). 'L'histoire des prix des céréales en France, dans la seconde moitié du XVII ${ }^{\mathrm{e}}$ siècle'. Mélanges d'histoire sociale 5, pp. 27-44. DOI: 10.3406/ahess.1944.3104.

Mouchel-Vallon, Patrice (2017). 'Croquants, rebelles et ligueurs en Cotentin à la fin du XVI siècle. La réécriture politique d'une révolte et de ses composantes : prosopographie de l'émeute, du saccage et du meurtre'. PhD Thesis. Université de Caen, p. 1012.

Perrot, Jean-Claude (1975). Genèse d'une ville moderne : Caen au XVIII siècle. 2 vols. Paris: Mouton, p. 1157.

Peuchet, Jacques (1799). Dictionnaire universel de la géographie commerçante. Tome 5. Paris: Blanchon, p. 829.

Poncet, Fabrice (2019). 'L'Église face au couchage en herbe dans les diocèses de Coutances et de Bayeux'. In: Prudhomme, Louis Marie. Du ciel à la terre : Clergé et agriculture, XVI ${ }^{e}-X I X^{e}$ siècle. Rennes: Presses Universitaires de Rennes, pp. 177-189. 
Porquet, Louis (1989). La peste en Normandie : du XIVe au XVII siècle. Vire: Imprimerie René Eng, p. 256.

Ridolfi, Leonardo (2019). 'Six Centuries of Real Wages in France from Louis IX to Napoleon III: 1250-1860'. The Journal of Economic History 79.3, pp. 1-39. DOI: 10.1017/S0022050719000354.

- (2021). 'The Days They Worked, the Incomes They Earned: NewPperspectives on Work Patterns and Annual Earnings in the French Construction Sector (1320-1850)'. Rivista di storia economica 2, pp. 115-150. DOI: 10.1410/100982.

Robillard de Beaurepaire, Charles de (1889). Renseignements statistiques sur l'état de l'agriculture vers 1789. Rouen: Imprimerie Espérance Cagniard, p. 113.

Rota, Mauro and Jacob Weisdorf (2020). 'Italy and the Little Divergence in Wages and Prices: New Data, New Results'. The Journal of Economic History 80.4, pp. 931-960. DOI: 10.1017/ S0022050720000467.

- (2021). 'Italy and the Little Divergence in Wages and Prices: Evidence from Stable Employment in Rural Areas'. The Economic History Review 74.2, pp. 449-470. DOI: 10.1111/ehr.13023.

Rudé, George and Albert Soboul (1954). 'Le maximum des salaires parisiens et le 9 thermidor'. 134, pp. 1-22.

Saugrain, Claude-Marin (1709). Dénombrement du royaume par généralités, élections, paroisses et feux. 2 vols. Paris.

Sauzeau, Thierry (2013). 'La pluriactivité des marins du long cours au XVIII siècle'. Annales de Bretagne et des pays de l'Ouest 120.2, pp. 65-78. DOI: 10.4000/abpo.2618.

Savary des Bruslons, Jacques (1765). Dictionnaire universel de commerce, d'histoire naturelle, $\mathcal{E}$ des arts \& métiers. Vol. 5. Copenhague: Claude Philibert, p. 1733.

Sion, Jules (1909). Les paysans de la Normandie orientale. Pays de Caux, Bray, Vexin normand, Vallée de la Seine. Étude géographique. Paris: Armand Colin, p. 288.

Stephenson, Judy Z. (2018). “Real' Wages? Contractors, Workers, and Pay in London Building Trades, 1650-1800'. The Economic History Review 71.1, pp. 106-132. DOI: 10.1111/ehr.12491.

Vidalenc, Jean (1946). 'L'industrie dans les départements normands à la fin du Premier Empire'. Annales de Normandie 7.3-4, pp. 281-307. DOI: 10.3406/annor.1957.4358.

Wailly, Natalis de (1857). Mémoire sur les variations de la livre tournois depuis le règne de saint Louis jusqu'à l'établissement de la monnaie décimale. Paris: Impr. Impériale, p. 251. 


\title{
Online appendix
}

The Evolution of Wages in Early Modern Normandy (1600-1850)

\author{
CÉDRIC CHAMBrU \\ University of Zurich
}

Paul Maneuvrier-Hervieu

University of Milan 


\section{Contents}

A Additional information on data 4

A.1 Metrology .......................... 4

A.2 Currency ............................. 5

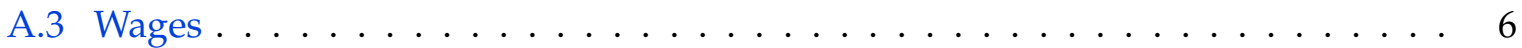

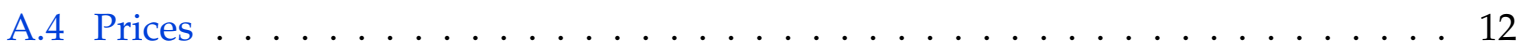

B The composition of the consumption basket 16

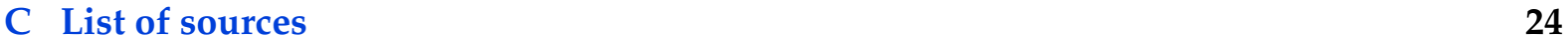

Primary sources . . . . . . . . . . . . . . . . . . . . . . . 24

Secondary sources . . . . . . . . . . . . . . . . . . . 32

$\begin{array}{ll}\text { Online Appendix References } & 40\end{array}$

\section{List of Figures}

A.1 Silver weight for the livre tournois and French franc, 1601-1860 . . . . . . . . . 5

A.2 The spatial distribution of wage observations . . . . . . . . . . . 8

A.3 The distribution of wage observations by location and by decade . . . . . . . . 9

A.4 The distribution of wage observations by type of sources . . . . . . . . . . . 9

A.5 The nominal daily wage for skilled construction labour in Normandy and France, $1601-1850$. . . . . . . . . . . . . . . . . . . . . 10

A.6 The casual working year needed to earn the annual contract income in Normandy, 1601-1850 . . . . . . . . . . . . . . . . . . . . 10

A.7 The welfare ratio for stable agricultural labourers in Normandy, 1601-1850 . . . . 11

A.8 The spatial distribution of price observations $\ldots \ldots \ldots \ldots$

A.9 The distribution of price observations by type of sources . . . . . . . . . . . . 14

A.10 The distribution of price observations by location $\ldots \ldots \ldots$. . . . . . . 14

A.11 Number of price observations by commodity . . . . . . . . . . . . . . . . 15

A.12 The evolution of wheat prices in rural and urban Normandy, 1601-1850 . . . . 15

A.13 The consumer price index . . . . . . . . . . . . . . . . 22

A.14 The consumer price index in grams of silver in Normandy, 1601-1850 . . . . . . . 22

A.15 The consumer price index in England and Normandy, 1601-1850 . . . . . . . . 23

A.16 The daily cost of food in a respectability basket in Normandy, 1601-1850 . . . . . 23

A.17 Example of document used to build the database on wages . . . . . . . . . . . 30

A.18 Example of document used to build the database on prices . . . . . . . . . . . 31

\section{List of Tables}

A.1 Description of the variables in the metrology database . . . . . . . . . . . 4

A.2 Description of the variables in the wage database . . . . . . . . . . . 6 
A.3 The distribution of wage observations by occupation and by gender . . . . . 7

A.4 The distribution of wage observations by occupation and by area $\ldots \ldots \ldots$

A.5 Description of the variables in the price database . . . . . . . . . . . . 12

A.6 The consumption basket . . . . . . . . . . . . . . . . . . 18

A.7 The consumption basket at the Congrégation de Notre-Dame de Rouen, June 164518

A.8 The consumption basket for a family in Rouen, c. 1700 . . . . . . . . . . . . . 19

A.9 The consumption basket at the Abbey Notre-Dame d'Aunay, 1644 . . . . . . . . . 19

A.10 The consumption basket for the Earl of Roncherolles in Pont-Saint-Pierre, October 1746-December 1747 . . . . . . . . . . . . . . . . . . . . 20

A.11 The consumption basket for the Marquis of Ledoulcet de Pontécoulant, c. 1770s . 20

A.12 The bare bone consumption basket for a family in Caen, 1844 . . . . . . . . . . 21

A.13 The cost of living across social groups in Eure, c. 1800 . . . . . . . . . . . . . 21 


\section{A Additional information on data}

\section{A.1 Metrology}

Before the introduction of the metric system during the French Revolution, weights and measures varied considerably by place, time and substances measured. The lack of a uniform system often hindered regional and interregional trade, and, sometimes, made the payment of rents difficult. We assembled a new database on metrology in Normandy to convert all our commodities into their metric equivalent. For instance, cereals are always expressed in litres, as is cider, while meat and butter is given in $\mathrm{kg}$. In total, we collected 653 unique entries covering more than 100 locations. Table A.1 provides the list of variables in the database and their description.

Table A.1: Description of the variables in the metrology database

\begin{tabular}{|c|c|}
\hline Variable name & Variable description \\
\hline id & unique identifier \\
\hline town & name of the town where the unit of measure is used \\
\hline year start & year after which the unit of measure is used \\
\hline year end & year after which the unit of measure is no longer used \\
\hline type unit & type of unit of measure, e.g. aune, boisseau, pot \\
\hline name unit & name of the unit of measure \\
\hline commodity & name of the commodity \\
\hline capacity type & metric equivalent of the unit of measure, e.g. kg, litre, metre \\
\hline capacity unit & capacity of the unit of measure in metric equivalent \\
\hline secondary sources & reference of the article/book from which the information was taken \\
\hline primary sources & signature of the archive from which the information was taken \\
\hline comments & relevant comment on the unit entry \\
\hline
\end{tabular}

Notes: The variables year start and year end are only indicative. In most cases, the capacity of the unit remained constant over time. In a few cases, however, capacity was re-evaluated and set at a new level. We used these variables to distinguish the variations in capacity within the same unit. When a unit is valid for all towns, e.g. the hectolitre for cereals, we left the variable town empty. We used the variable comments to include additional information on the unit of measure, in particular if a source gives a different metric equivalent. 


\section{A.2 Currency}

Before the introduction of the Franc germinal in 1803, the currency used as a unit of account was the livre tournois, which was subdivided into 20 sols or 240 deniers. Its silver weight varied from 12.39 grams in the early 17 th century to 4.70 grams from 1726 onward (Figure A.1). It should also be noted that the conversion of the livre tournois in grams of silver for the period 1690-1725 must be interpreted with caution due to the numerous monetary changes made by the King and the low reliability of the series used for the conversion (Wailly 1857).

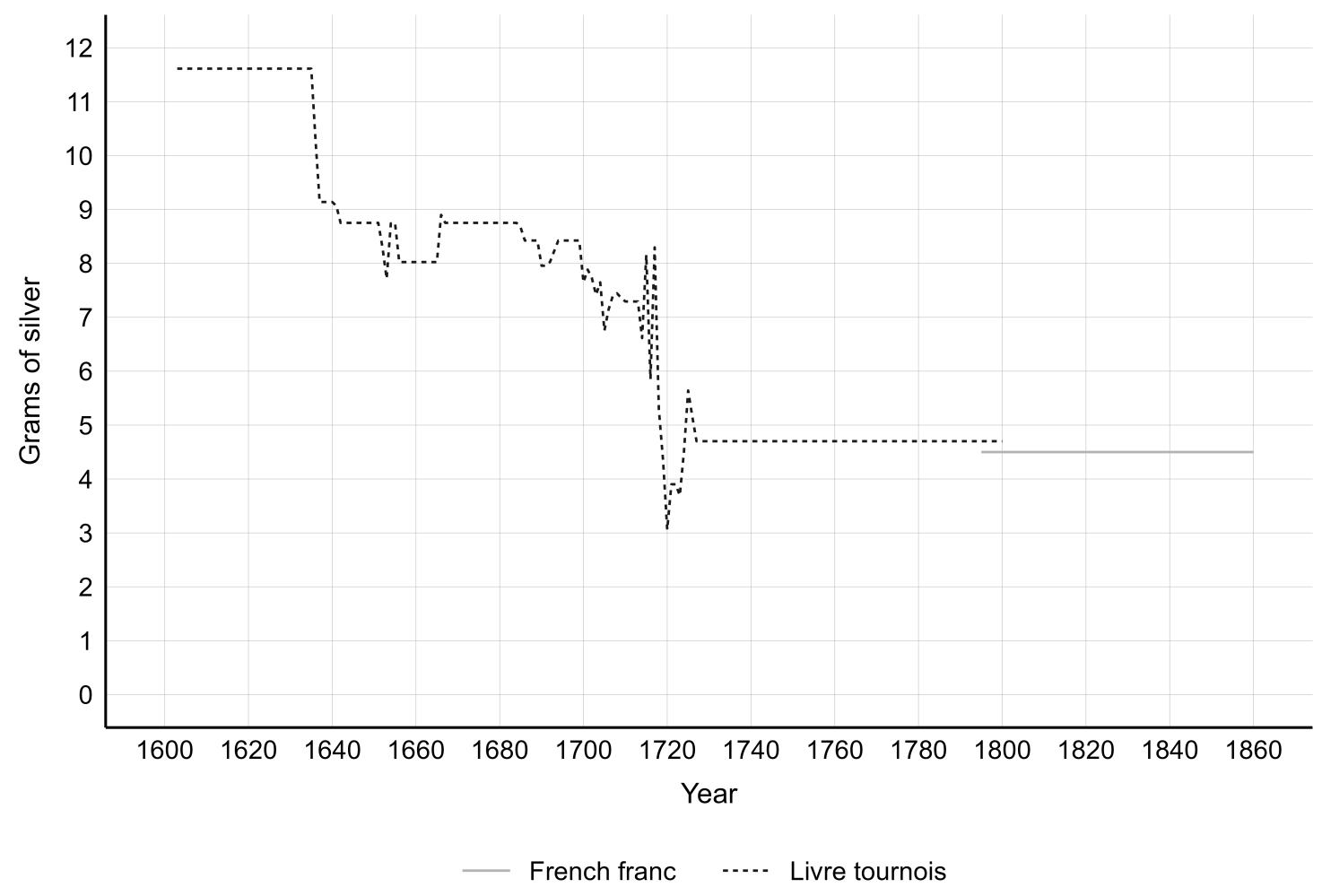

Sources: Original data from Allen (2001) derived from Wailly (1857).

Figure A.1: Silver weight for the livre tournois and French franc, 1601-1860 


\section{A.3 Wages}

In this section, we provide additional figures and tables to describe the newly-collected wage data set. In Table A.2, we summarise the variables contained in the database. The list of sources used to build the data set is grouped with those for prices in Online Appendix Section C.

Table A.2: Description of the variables in the wage database

\begin{tabular}{|c|c|}
\hline Variable name & Variable description \\
\hline id & unique identifier \\
\hline decade & decade when the payment was made \\
\hline year & year in which the payment was made \\
\hline month & month in which the payment was made \\
\hline day & day in which the payment was made \\
\hline time & other relevant information on the timing, e.g. St John, Christmas \\
\hline town & town where the payment was made \\
\hline generalite & généralité where the payment was made \\
\hline urban & categorical variable regional, rural, or urban areas \\
\hline occupation & occupation of the labourer in French \\
\hline occupation type & classification of occupations, e.g. unskilled, textile, agricultural labour \\
\hline gender & gender of the labourer as given in the sources or deduced from the surname \\
\hline surname & surname of the labourer \\
\hline family name & family name of the labourer \\
\hline name employer & name of the employer \\
\hline wage type & categorical variable: yearly, monthly, weekly, or daily \\
\hline nb days worked & number of days worked to receive the payment \\
\hline original currency & currency in which the wage payment was reported \\
\hline original wage & day wage of the labourer in livres tournois or French francs (resp. yearly, monthly, weekly) \\
\hline dummy fed & dummy variable indicating whether the labourer was fed by the employer \\
\hline wage kind & description of the food and materials received as payment in kinds, if any \\
\hline standard wage & day wage of the labourer including food in livres tournois or French francs \\
\hline conversion & silver equivalent of the original currency \\
\hline standard wage ag & standard wage in grams of silver \\
\hline sources type & type of sources where the payment was recorded \\
\hline secondary sources & reference of the article/book from which the wage payment was taken \\
\hline primary sources & signature of the archive from which the wage payment was taken \\
\hline comments & relevant comment on the wage entry \\
\hline
\end{tabular}

Notes: The silver equivalent of the original currency is derived from Allen (2001). 
Table A.3: The distribution of wage observations by occupation and by gender

\begin{tabular}{lcccc}
\hline Occupation & Male & Female & Child & Total \\
\hline Agricultural labourer & 5,097 & 797 & 154 & 6,048 \\
Service labourer & 122 & 2 & 0 & 124 \\
Skilled construction labourer & 4,967 & 0 & 7 & 4,974 \\
Skilled craftsman labourer & 803 & 16 & 5 & 824 \\
Skilled craftsman maritime labourer & 347 & 0 & 0 & 347 \\
Textile labourer & 560 & 212 & 43 & 815 \\
Unskilled labourer & 1,741 & 396 & 19 & 2,156 \\
Unskilled maritime labourer & 4,591 & 0 & 0 & 4,591 \\
Total & 18,228 & 1,423 & 228 & 19,879 \\
\hline
\end{tabular}

Sources: See Section 2.2 and Online Appendix Section C.

Table A.4: The distribution of wage observations by occupation and by area

\begin{tabular}{lccc}
\hline Occupation & Rural & Urban & Total \\
\hline Agricultural labourer & 5,947 & 101 & 6,048 \\
Service labourer & 101 & 23 & 124 \\
Skilled construction labourer & 3,730 & 1,244 & 4,974 \\
Skilled craftsman labourer & 565 & 259 & 824 \\
Skilled craftsman maritime labourer & 74 & 273 & 347 \\
Textile labourer & 378 & 439 & 817 \\
Unskilled labourer & 1,548 & 608 & 2,156 \\
Unskilled maritime labourer & 1,751 & 2,840 & 4,591 \\
Total & 14,094 & 5,787 & 19,881 \\
\hline
\end{tabular}

Sources: See Section 2.2 and Online Appendix Section C. 


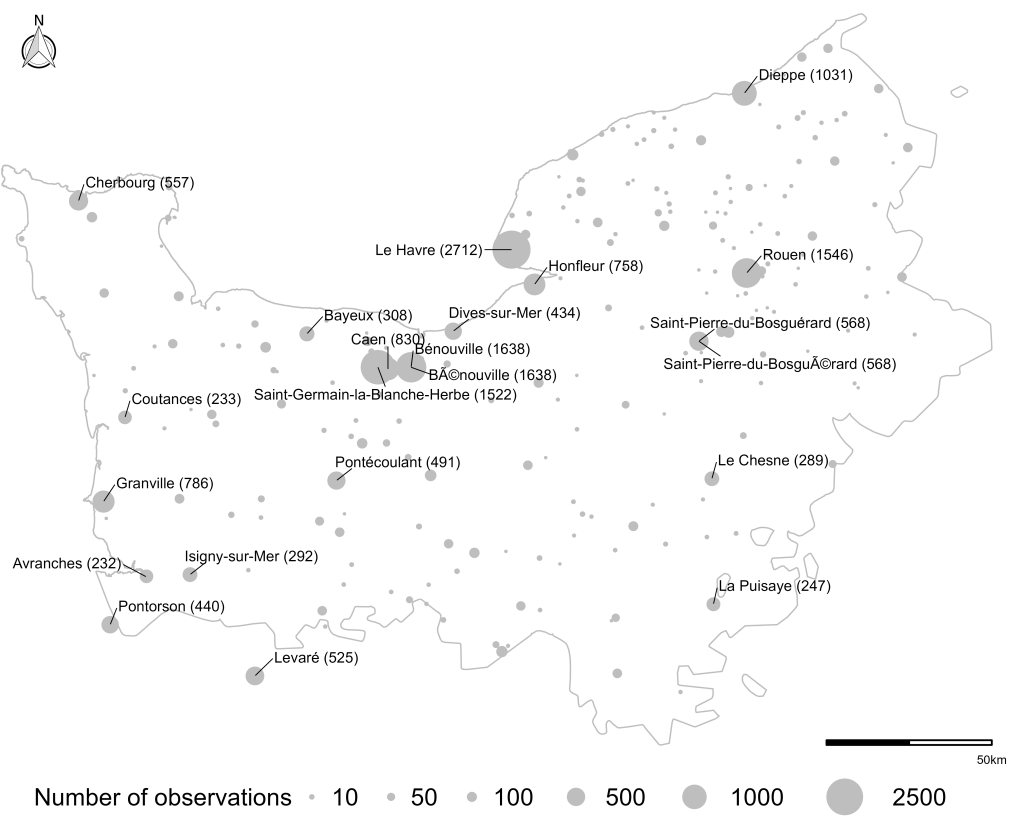

Sources: See Section 2.2 and Online Appendix Section C.

Figure A.2: The spatial distribution of wage observations 


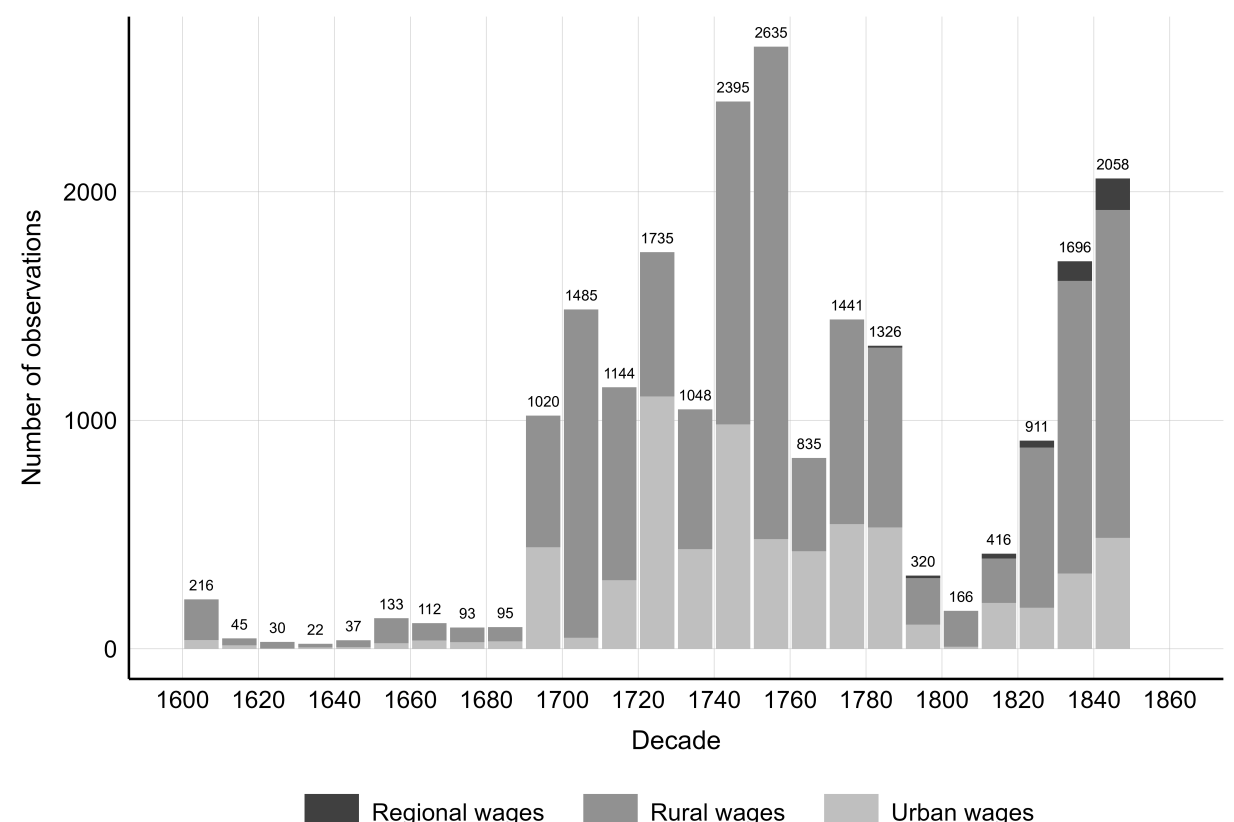

Notes: The threshold to include a town in the urban category is 10,000 inhabitants in 1793 . Urban locations include the cities of Rouen, Caen, Dieppe, Le Havre, Falaise, Alençon, Bayeux, Lisieux, and Cherbourg. Regional wages correspond to the regional average computed by the French administration during the 19th century and/or other scholarly works.

Sources: See Section 2.2 and Online Appendix Section C.

Figure A.3: The distribution of wage observations by location and by decade

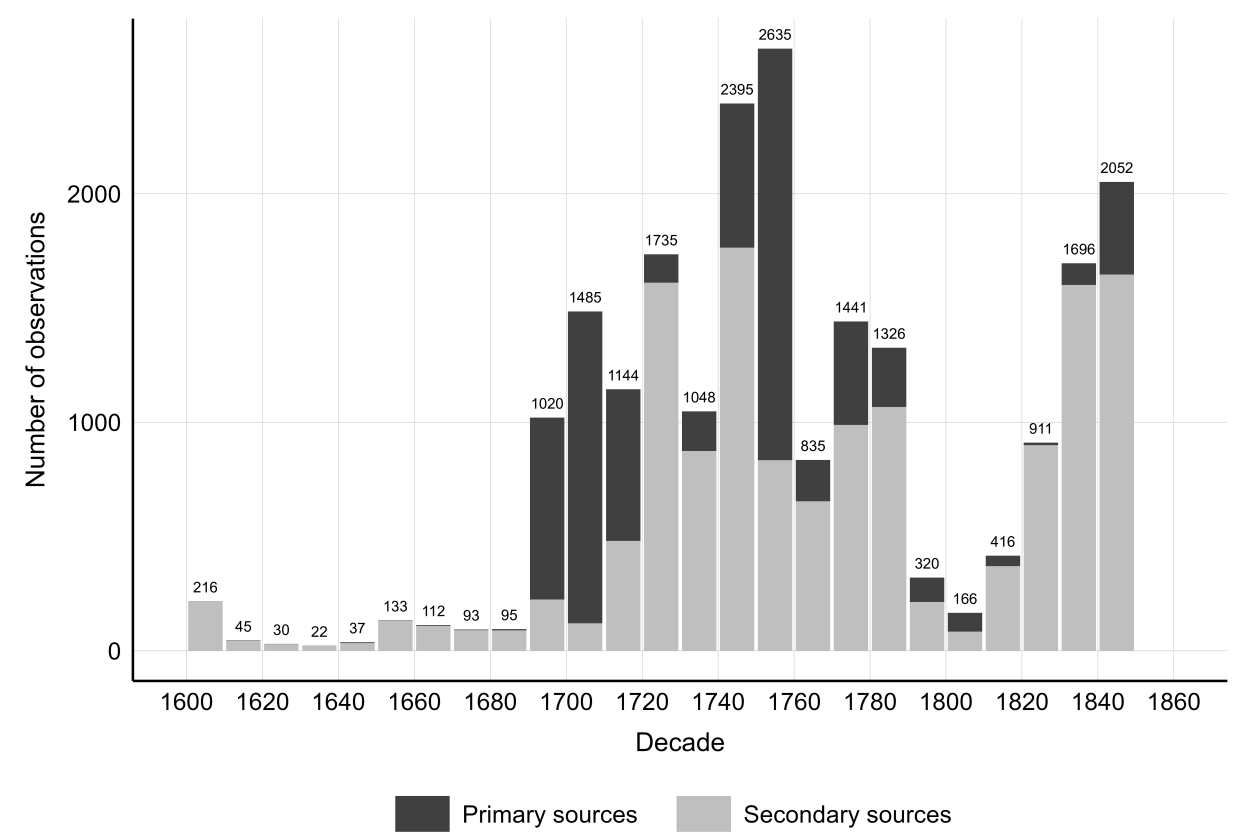

Sources: See Section 2.2 and Online Appendix Section C.

Figure A.4: The distribution of wage observations by type of sources 


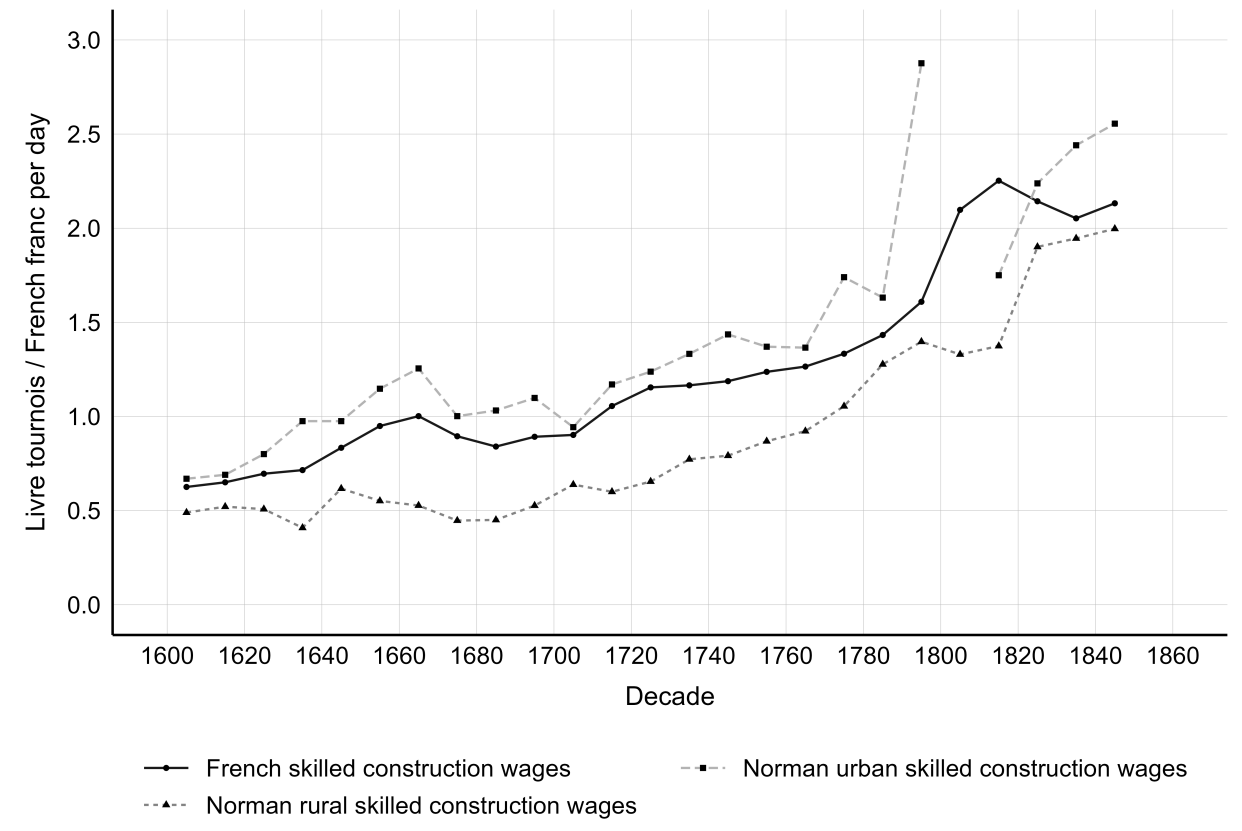

Sources: See Section 2.2 and Online Appendix Section C. Data for France are from Ridolfi (2019).

Figure A.5: The nominal daily wage for skilled construction labour in Normandy and France, $1601-1850$

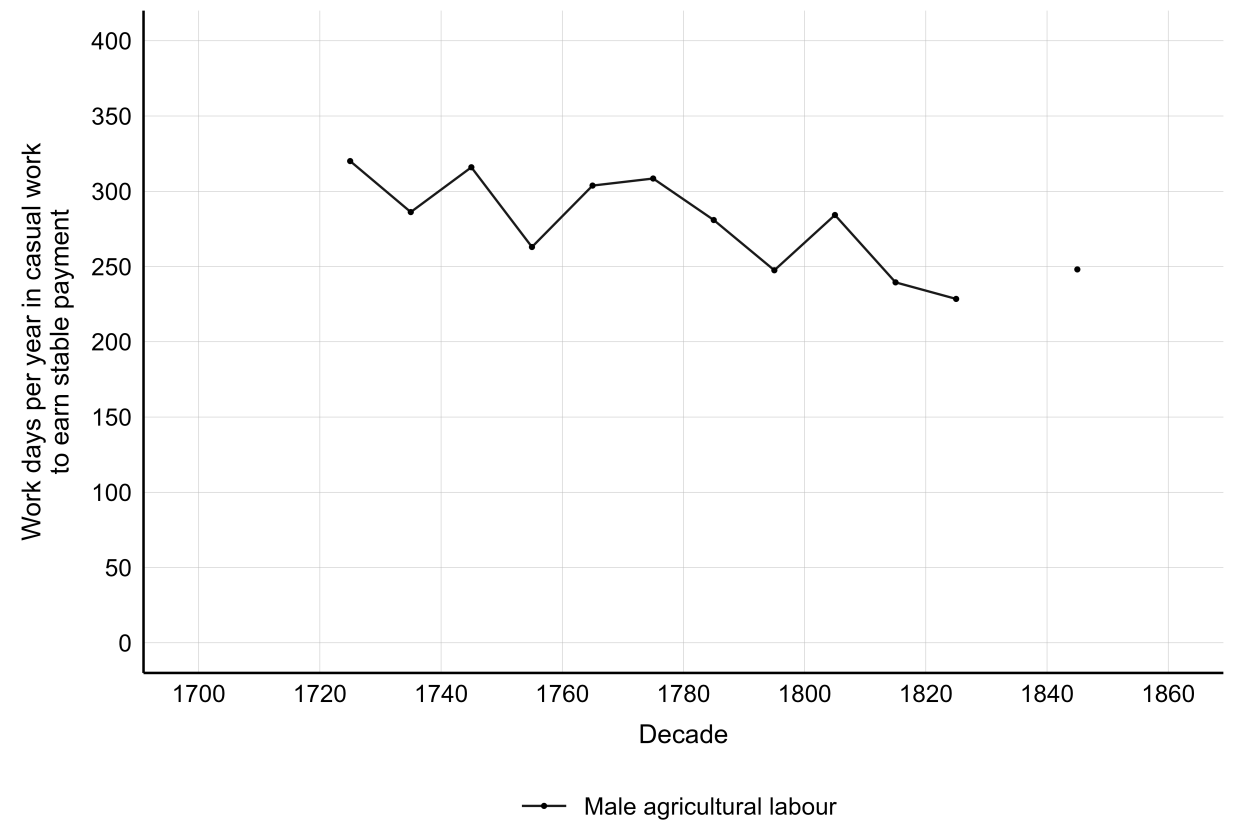

Sources: See Section 2.2 and Online Appendix Section C.

Figure A.6: The casual working year needed to earn the annual contract income in Normandy, $1601-1850$ 


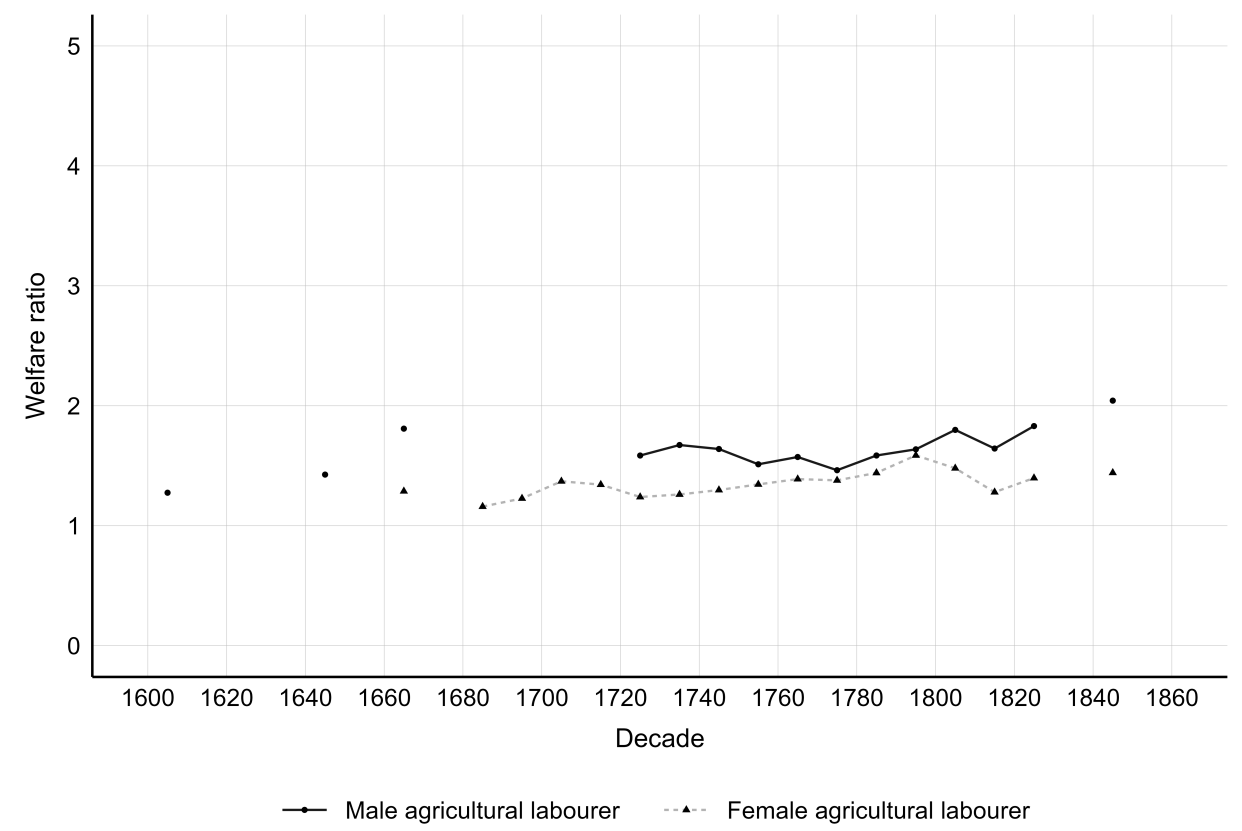

Notes: To account for in-kind payment, we added to the annual payment the cost of one annual consumption basket, including board and lodging. The welfare ratio is obtained by dividing the total annual earnings by the cost of one respectability basket.

Sources: See Section 2.2 and Online Appendix Section C.

Figure A.7: The welfare ratio for stable agricultural labourers in Normandy, 1601-1850 


\section{A.4 Prices}

In this section, we provide additional figures and tables to describe the newly-collected wage data set. In Table A.5, we summarise the variables contained in the database. The list of sources used to build the data set is grouped with those for prices in Online Appendix Section C.

Table A.5: Description of the variables in the price database

\begin{tabular}{|c|c|}
\hline Variable name & Variable description \\
\hline id & unique identifier \\
\hline decade & decade when the price was recorded \\
\hline year & year in which the price was recorded \\
\hline month & month in which the price was recorded \\
\hline day & day in which the price was recorded \\
\hline time & other relevant information on the timing, e.g. St John, Christmas \\
\hline town & town where the purchase was made \\
\hline generalite & généralité where the price was recorded \\
\hline urban & categorical variable regional, rural, or urban areas \\
\hline original commodity & name of the commodity as indicated in the source \\
\hline standard commodity & cleaned name of the commodity \\
\hline commodity type & classification of the commodity in general type, e.g. crops, heating, meat \\
\hline quantity & quantity of commodities purchased \\
\hline original currency & currency in which the price was reported \\
\hline original price & price of the commodity for one unit in livres tournois or French francs \\
\hline original unit & name of the original unit of measure, e.g. mine de Rouen \\
\hline capacity type & metric equivalent of the unit of measure, e.g. $\mathrm{kg}$, litre, metre \\
\hline capacity unit & capacity of the unit of measure in metric equivalent \\
\hline standard price & price of the commodity for one unit in metric equivalent in livres tournois or French francs \\
\hline standard unit & name of the standard unit of measure \\
\hline conversion & silver equivalent of the original currency \\
\hline standard price ag & standard price in grams of silver \\
\hline sources type & type of sources where the price was recorded \\
\hline secondary sources & reference of the article/book from which the price was taken \\
\hline primary sources & signature of the archive from which the price was taken \\
\hline comments & relevant comment on the price entry \\
\hline
\end{tabular}

Notes: The silver equivalent of the original currency is derived from Allen (2001). 


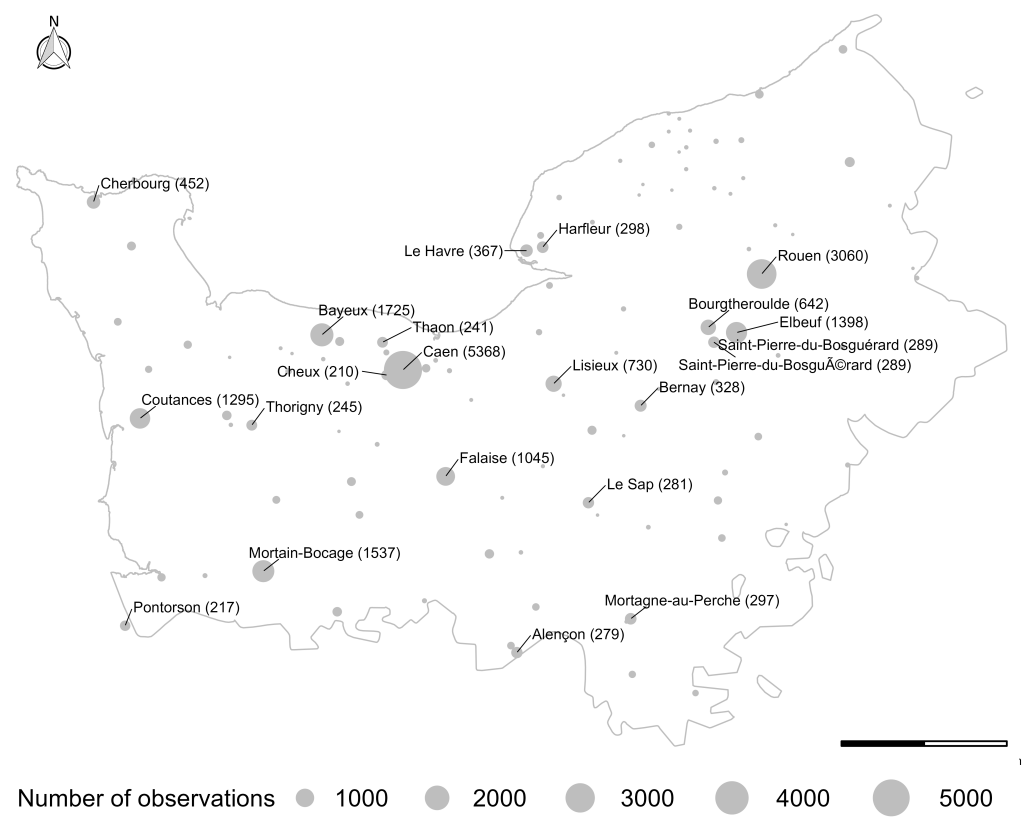

Sources: See Section 2.3 and Online Appendix Section C.

Figure A.8: The spatial distribution of price observations 


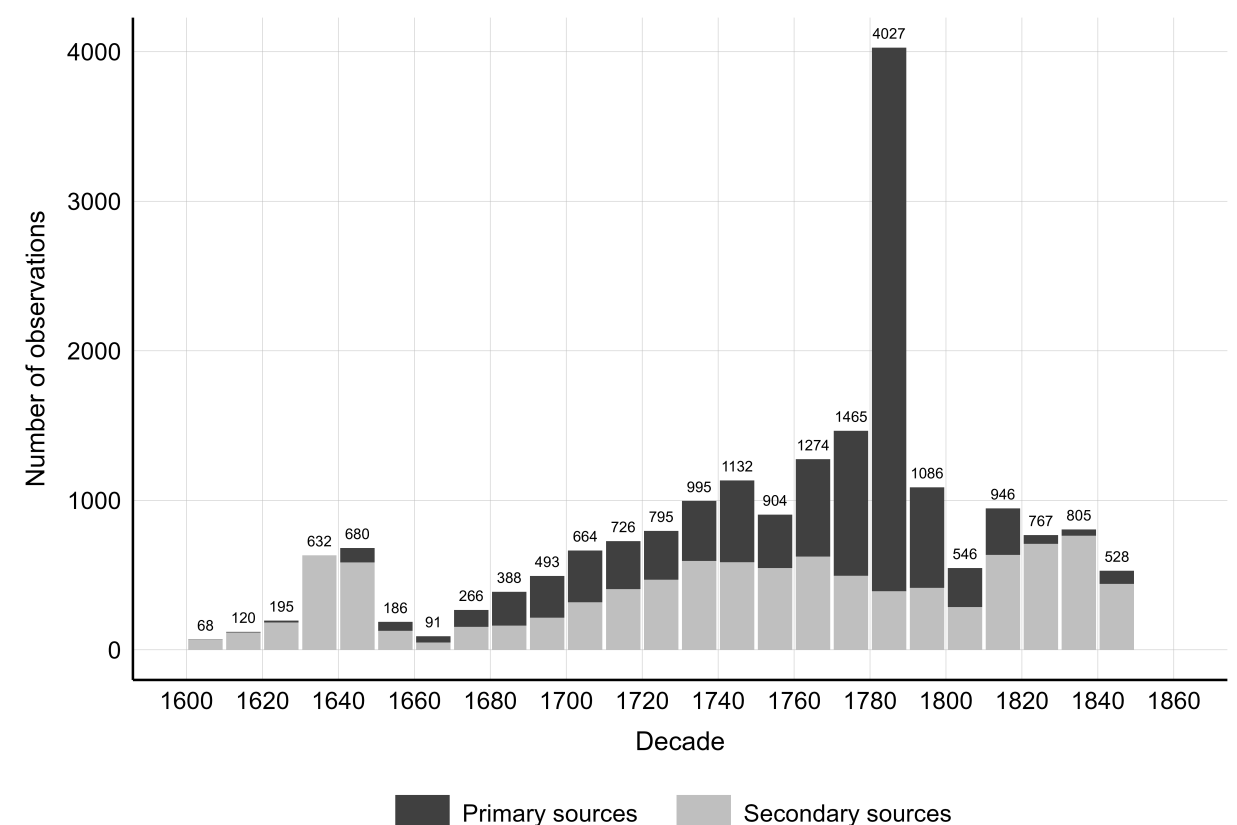

Sources: See Section 2.3 and Online Appendix Section C.

Figure A.9: The distribution of price observations by type of sources

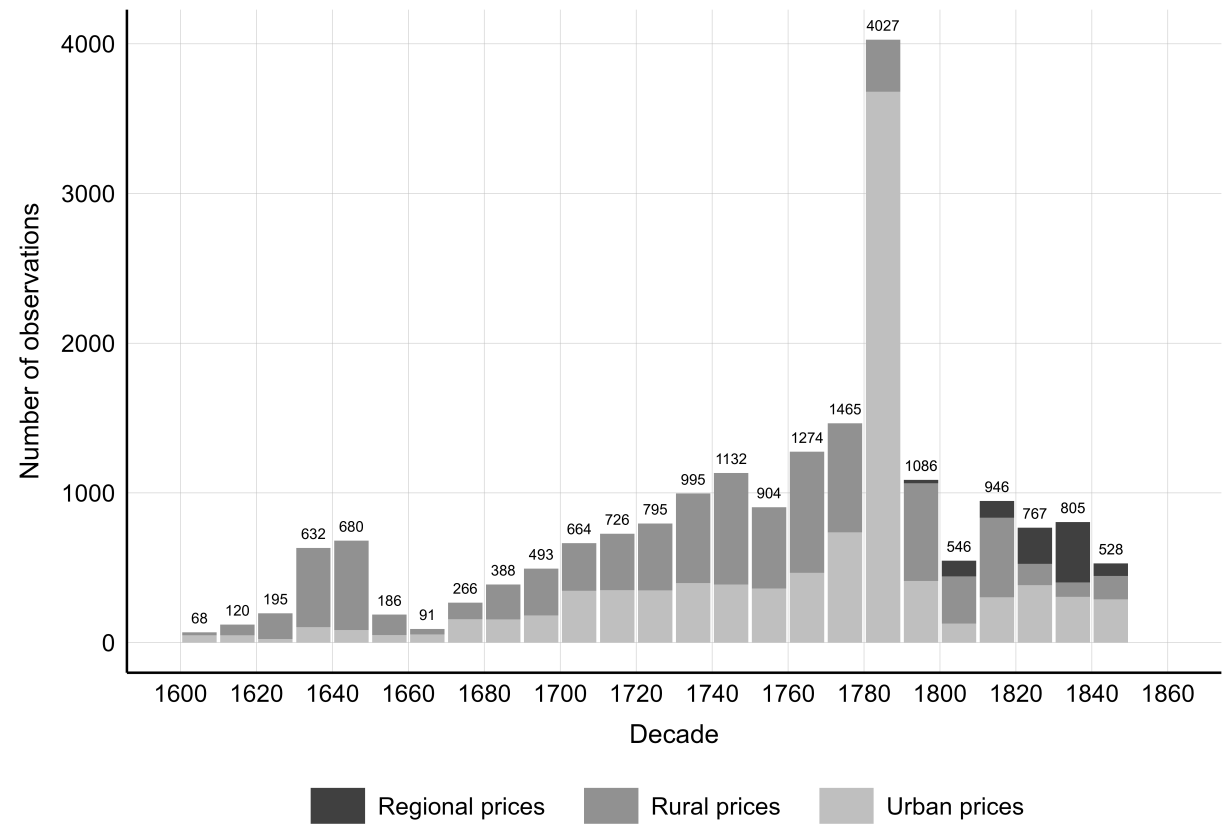

Notes: The threshold to include a town in the urban category is 10,000 inhabitants in 1793. Urban locations include the cities of Rouen, Caen, Dieppe, Le Havre, Falaise, Alençon, Bayeux, Lisieux, and Cherbourg. Regional prices correspond to the regional average computed by the French administration during the 19th century and/or other scholarly works.

Sources: See Section 2.3 and Online Appendix Section C.

Figure A.10: The distribution of price observations by location 


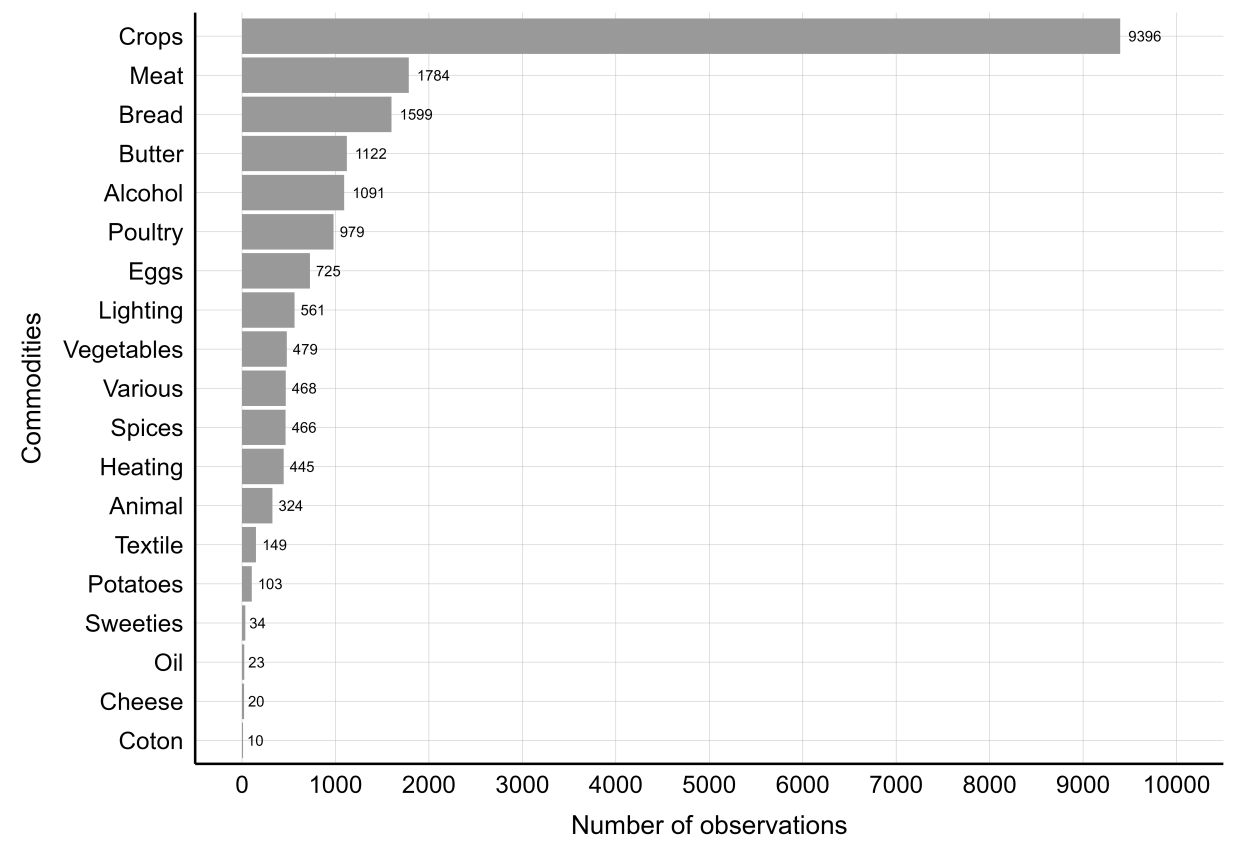

Sources: See Section 2.3 and Online Appendix Section C.

Figure A.11: Number of price observations by commodity

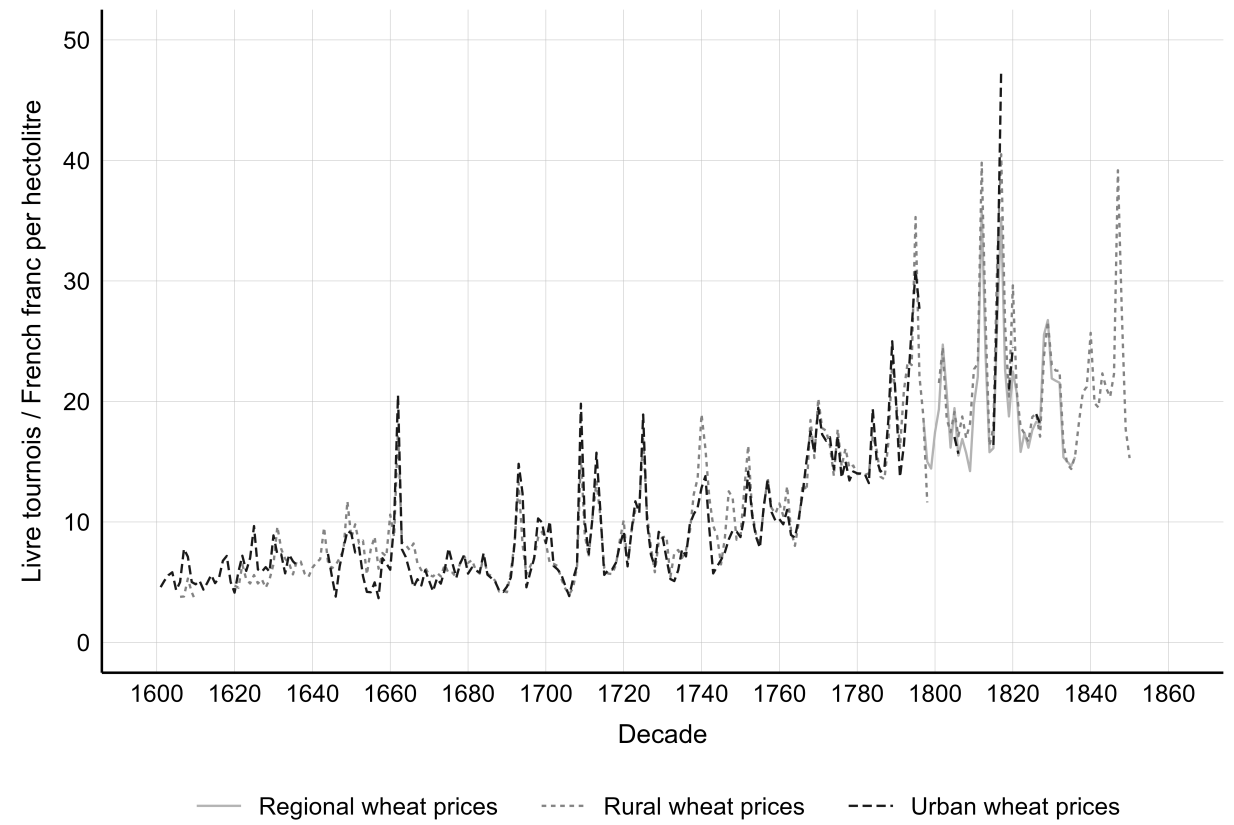

Notes: The series for rural prices is based on 2,492 observations. The series for urban prices is based on 1,772 observations. The correlation between both series is 0.945 . Sources: See Section 2.3 and Online Appendix Section A.4.

Figure A.12: The evolution of wheat prices in rural and urban Normandy, 1601-1850 


\section{B The composition of the consumption basket}

This section describes the methodology developed to establish a consumption basket to convert the nominal wages into real wages. We followed Humphries' critique and adjustments on the number of daily calories necessary for an adult person (Humphries 2013) and set the daily amount of kcal at 1,900 and 2,500 for the bare bones subsistence basket and the respectability basket, respectively (Online Appendix Table A.6). Therefore, we used $234 \mathrm{~kg}$ of bread per year, or 640 grams of bread per day, as a baseline for our respectability basket. This amount was probably a minimum. Lemarchand (1989, p. 186) points out that, in 1705, a single adult in Rouen spent about 33 livres tournois per year to consume 2 livres pesants of bread per day. In the 1770s, daily labourers usually received 2 livres pesants of bread and 1 pot of cider per day (Perrot 1975, p. 786). ${ }^{1}$

We decided not to make a distinction between rural and urban areas and to compute only one CPI for the entire province of Normandy. ${ }^{2}$ We made this decision after the Online Appendix Figure A.12, which charts the evolution of wheat prices in urban and rural areas between 1601 and 1850 and shows that prices did not vary much in either level or and trends across cities and the countryside. ${ }^{3}$

In Appendix Tables A.9 to A.12, we present a set of consumption baskets for various social groups and institutions in Normandy between 1601 and 1850. In all baskets, bread was one of the main staple articles, together with meat and fish and, to some extent, dairy products (butter and cheese). We used these consumption baskets to inform our choice on the composition of our standard respectability basket for early modern Normandy. For instance, we used butter rather than oil as the main source of fat to respect the consumption habits of Norman households. ${ }^{4}$ Similarly, we selected cider as a beverage rather beer or wine, which was mostly drunk by the wealthier echelons of the Norman society. ${ }^{5}$ We further decided to include meat and poultry as a source of animal proteins, but not fish. ${ }^{6}$

Our estimations yield a respectability basket costing between 50 livres tournois in the early 16th century and about 100 livres tournois in the mid-18th century before reaching 200 French francs during the 19th century (Online Appendix Figure A.13). ${ }^{7}$ These estimates fit relatively

1 Using the account books from the Caen and Bayeux hospices, Désert (1977, pp. 154-70) estimates that the daily ration of bread was about 500 grams and butter about 10 grams in the first decades of the 19th century. Between 1812-4 and 1825-9, daily consumption of meat could have increased from approximately 60 grams to 100 grams. As for cider, its consumption amounted to 0.6 litre in Caen between 1825 and 1850. Overall, the daily ration provided to beggars included 1,900 calories (p. 156).

2 That means that we could pool rural and urban prices, which resulted in less missing data on the annual prices for consumption goods. Therefore, we also had to do less imputation to compute the series for the annual CPI.

3 Focusing on the 19th century, Désert (1977, pp. 42-5) arrives to the same conclusion: prices of bread and meat did not varied much between urban and rural areas in Western France.

4 We also used butter as proxy for dairy products instead of cheese. Cheese varied a lot by provenance, quality, and shape which makes any information on prices hardly comparable. Therefore, we doubled up the quantity of butter to $10.4 \mathrm{~kg}$.

5 We selected a volume of cider (240 litres) that provides the same amount of kcal as beer or wine.

6 Even though fish was widely consumed on the coast of Normandy, the few occurrences of prices in the sources and the variety of fishes make it difficult to assemble a reasonable series of prices for this commodity.

7 For a discussion on the evolution of the CPI trends, see Section 4.1. 
well with the scant historical evidence we found on the cost of living in early modern Normandy. For instance, Lemarchand (1989, p. 186) reports that, in addition to 33 livres tournois of bread, a single adult would spend 22 livres tournois on other staple articles, while its cost of accommodation ranged between 10 and 20 livres tournois. Adding up the cost of firewood (5-10 livres tournois) and taxes (8-9 livres tournois), his total annual expenditure would have been around 85 livres tournois per year. Fifty years later, the priory of Saint-du-Vieux-deBellême spent 700 livres tournois per year to cover the food consumption of their 7 domestic servants. That amounts to roughly 5.5 sols per day per person. ${ }^{8}$ Writing about the workingclass families in Calvados, Durand (1850, p. 121) noted that, according to the 1848 industrial survey, the cost of living for a household composed of two adults and two young children was 600 French francs, where one single male adult needed 300 French francs to sustain himself. Of course, wealthier groups, such as the Sisters from the Congrégation de Notre-Dame de Rouen, were able to maintain higher standards of living with more expensive consumption baskets (Online Appendix Table A.7 and Table A.13). Similarly, in the late 17th century, the Sisters of the monastery of the Visitiation in Alençon spent 5,600 livres tournois per year on staple foods for 37 adults and one girl, equivalent to 8.18 sols per day per person. ${ }^{9}$

8 Arch. dép. Orne, H 2131, Prieuré de Saint-du-Vieux-de-Bellême, État des revenus et des charges et des cens et rentes, $1740-1761$.

9 Arch. dép. Orne, H 4970, Monastère de la Visitiation d'Alençon, 1683-1695. 
Table A.6: The consumption basket

\begin{tabular}{lcccc}
\hline & $\begin{array}{c}\text { Quantity per year } \\
\text { per person }\end{array}$ & Unit & kcal/unit & kcal/day \\
\hline Wheat bread & 234 & $\mathrm{~kg}$ & 1,571 \\
Beans & 52 & $\mathrm{~kg}$ & 370 \\
Meat & 13 & $\mathrm{~kg}$ & 178 \\
Poultry & 13 & $\mathrm{~kg}$ & 178 \\
Butter & 10.4 & $\mathrm{~kg}$ & 104 \\
Eggs & 52 & each & 11 \\
Cider & 240 & 1 & 210 \\
Soap & 2.6 & $\mathrm{~kg}$ & \\
Linen & 5 & $\mathrm{~m}$ & \\
Candles & 5.2 & $\mathrm{~kg}$ & & \\
Firewood & 0.837 & $\mathrm{~m}$ & \\
Rent & $5 \%$ & & & \\
\hline
\end{tabular}

Notes: Information on bread prices being are scant. We derived bread prices from wheat prices following Allen (2001, pp. 418-9). We chose to use a metric equivalent to calculate the amount of heating rather than the British Thermal Unit (BTU). $0.837 \mathrm{~m}^{3}$ (stère) of wood is roughly equivalent to 5 millions BTU. Sources: Humphries (2013) and Online Appendix Section B.

Table A.7: The consumption basket at the Congrégation de Notre-Dame de Rouen, June 1645

\begin{tabular}{lcc}
\hline & $\begin{array}{c}\text { Expenditure } \\
\text { per month in } £\end{array}$ & \% expenditure \\
\hline Bread & 13.1 & 12.6 \\
Wheat & 6.9 & 6.6 \\
Fish & 5.6 & 5.6 \\
Meat & 32.7 & 31.4 \\
Peas & 3.45 & 3.3 \\
Butter, cheese & 10.53 & 10.1 \\
Salt, spices & 3.29 & 3.2 \\
Fruits & 9.71 & 9.3 \\
Wine, cider & 8.45 & 8.1 \\
Vinegar & 0.45 & 0.4 \\
Salad & 2.61 & 2.5 \\
Charcoal & 7 & 6.7 \\
\hline Total & 104 & \\
\hline
\end{tabular}

Notes: The expenditure in June yielded the equivalent of 6.93 sols per meal. From July to September 1646 (92 days), the five Sisters spent $£ 264.59$ to pay for their food, which is equivalent to 5.75 sols per meal (fol. 24).

Sources: Arch. dép. Seine-Maritime, D 555, Congrégation de Notre-Dame de Rouen, Livre de la dépense, 1644-1657, fol. 7-8. 
Table A.8: The consumption basket for a family in Rouen, c. 1700

\begin{tabular}{lcc}
\hline & $\begin{array}{c}\text { Expenditure } \\
\text { per day in } £\end{array}$ & \% expenditure \\
\hline Bread & 0.5 & 23.3 \\
Fish & 0.45 & 20.9 \\
Cheese & 0.25 & 11.6 \\
Cider & 0.6 & 27.9 \\
Others & 0.35 & 16.3 \\
\hline Total & 1.8 & 100 \\
\hline
\end{tabular}

Notes: The fish is herring. Le Pelletier reported that if a craftsman earned 15 sols per day, his wife 8 sols, and each of his children 5 sols, the total household income would be 43 sols, leaving 7 sols per day for commodities other than the staple foods.

Sources: Pelletier (1701, pp. 38-9). See Morineau (1972, pp. 210-9) for further a discussion on this household budget.

Table A.9: The consumption basket at the Abbey Notre-Dame d'Aunay, 1644

\begin{tabular}{lcc}
\hline & $\begin{array}{c}\text { Expenditure } \\
\text { per year in } £\end{array}$ & \% expenditure \\
\hline Wheat & 800 & 24.1 \\
Oats & 750 & 22.6 \\
Fish & 250 & 7.5 \\
Eggs & 250 & 7.5 \\
Butter & 400 & 12 \\
Salt & 30 & 0.9 \\
Wine & 150 & 4.5 \\
Cider & 300 & 9.0 \\
Textile & 230 & 6.9 \\
Candlelight & 80 & 2.4 \\
Firewood & 83 & 2.5 \\
\hline Total & 3,323 & \\
\hline Notes:
\end{tabular}

Notes: The monks used to consume wheat, whereas oats were for the domestic servants and the poor.

Sources: Le Hardy (1897, p. 167). 
Table A.10: The consumption basket for the Earl of Roncherolles in Pont-Saint-Pierre, October 1746-December 1747

\begin{tabular}{lcc}
\hline & $\begin{array}{c}\text { Expenditure } \\
\text { in } £\end{array}$ & \% expenditure \\
\hline Bread & 447.6 & 11.1 \\
Meat, poultry & $1,478.8$ & 36.5 \\
Fish & 253 & 6.8 \\
Oysters & 54.2 & 1.3 \\
Dairy, eggs & 47.9 & 1.2 \\
Vegetables, fruits & 627.2 & 15.5 \\
Condiments, jam & 90.5 & 2.2 \\
Sweets & 17.5 & 0.4 \\
Cider & 80 & 2.0 \\
Wine & 793.2 & 19.6 \\
Coffee & 9.9 & 0.2 \\
Various & 146.7 & 3.6 \\
\hline Total & $4,046.5$ & \\
\hline
\end{tabular}

Notes: Wine include specialised vintages such as Champagne, Hermitage, Chambertin, and Auxerre.

Sources: Dewald (1987, p. 195). Arch. dép. SeineMaritime, E, Fonds Caillot de Coquéraumont, liasse 1, Registre de recette et dépense.

Table A.11: The consumption basket for the Marquis of Ledoulcet de Pontécoulant, c. 1770s

\begin{tabular}{lcccc}
\hline & $\begin{array}{c}\text { Expenditure } \\
\text { in } £\end{array}$ & \% expenditure & $\begin{array}{c}\text { Summary } \\
\text { expenditure }\end{array}$ & \% expenditure \\
\hline Bread & 3,513 & 17.7 & Bread \& cereals & 24.9 \\
Cereals & 1,429 & 7.2 & Meat \& fish & 29.5 \\
Meat & 5,103 & 25.7 & Eggs & 3.1 \\
Fish & 781 & 3.9 & Dairy \& oil & 9.5 \\
Eggs & 618 & 3.1 & Salt \& sweets & 3.9 \\
Cheese & 28 & 0.1 & Drink & 11.4 \\
Butter & 1,466 & 7.4 & Fruits \& Vegetables & 13.1 \\
Oil & 397 & 2.0 & Various & 4.7 \\
Salt, spices & 483 & 2.4 & & \\
Sugar & 222 & 1.1 & & \\
Sweets & 69 & 0.3 & & \\
Cider & 763 & 3.8 & & \\
Wine & 1,407 & 7.1 & & \\
Liquor & 90 & 0.5 & & \\
Fruits & 2,566 & 12.9 & & \\
Vegetables & 34 & 0.2 & & \\
Various & 929 & 4.7 & & \\
\hline Total & 19,892 & 100 & & \\
\hline
\end{tabular}

Notes: The expenditure covers several years and includes the costs of food for both the family and their daily labourers and servants. Garnier (2004, pp. 163-4) estimates that the family provided the daily labourers with up to 80 livres pesants (roughly $40 \mathrm{~kg}$ ) of meat per year.

Sources: Garnier (2004, p. 132). 
Table A.12: The bare bone consumption basket for a family in Caen, 1844

\begin{tabular}{|c|c|c|c|c|c|}
\hline & $\begin{array}{l}\text { Expenditure per } \\
\text { year in Francs }\end{array}$ & $\%$ expenditure & $\begin{array}{l}\text { Quantity per day } \\
\text { per person }\end{array}$ & Unit & kcal/day \\
\hline Bread & 152.5 & 27.2 & 0.5 & $\mathrm{~kg}$ & 1,225 \\
\hline Soup & 127.75 & 22.8 & & & \\
\hline Meat & 46.8 & 8.4 & 0.06 & $\mathrm{~kg}$ & 142.5 \\
\hline Butter & 61.6 & 11.0 & & & 46 \\
\hline Cider & 18.2 & 3.2 & 0.14 & 1 & \\
\hline Textile & 67.1 & 12.0 & & & \\
\hline Lighting & 13.65 & 2.4 & & & \\
\hline Heating & 9.1 & 1.6 & & & \\
\hline Various & 23.7 & 4.2 & & & \\
\hline Rent & 40 & 7.1 & & & \\
\hline
\end{tabular}

Notes: The family is composed of two adults and one child. We assumed 2.5 adult equivalent for calculation purposes. An adult male working as a mason for 300 days earned 450 French francs per year; a carpenter about 495 French Francs. The daily kcal is only indicative and does not take into account the calorific input from soup and butter. Using data from the 1852 agricultural survey, Désert (1977, p. 177) estimates that a working-class family consumed $2,258 \mathrm{kcal} /$ day. It is noteworthy that, according the newspaper, 'the family is still destitute' with such a budget.

Sources: Le Haro : national normand, numéro du 01 août 1844.

Table A.13: The cost of living across social groups in Eure, c. 1800

\begin{tabular}{lcccccc}
\hline \multirow{2}{*}{ Social groups } & \multicolumn{2}{c}{ Daily cost of food } & \multicolumn{2}{c}{ Daily cost of accommodation } & \multicolumn{2}{c}{ Total expenditure } \\
& in 1789 & in 1800-1 & in 1789 & in 1800-1 & in 1789 & in 1800-1 \\
\hline Physician, lawmaker & 9.0 & 12 & 1.5 & 2.0 & 15 & 20 \\
Wealthiest landowner & 80 & 100 & 4.5 & 5.0 & 250 & 300 \\
Small landowner & 1.2 & 1.6 & 0.4 & 0.6 & 2.5 & 3.0 \\
Carpenter, shoemaker & 1.0 & 1.2 & 0.3 & 0.45 & 2.0 & 2.3 \\
Daily labourer, servant & 1.0 & 1.2 & 0.12 & 0.15 & 1.5 & 1.75 \\
\hline
\end{tabular}

Notes: The expenditure are expressed in French francs. Expenditure correspond to the cost of living for one individual. Masson de Saint-Amand further reported that the wage gap between fed and unfed daily labourers ranged between 0.6 to 1.0 Franc in 1789.

Sources: Masson de Saint-Amand (1805, p. 72). 


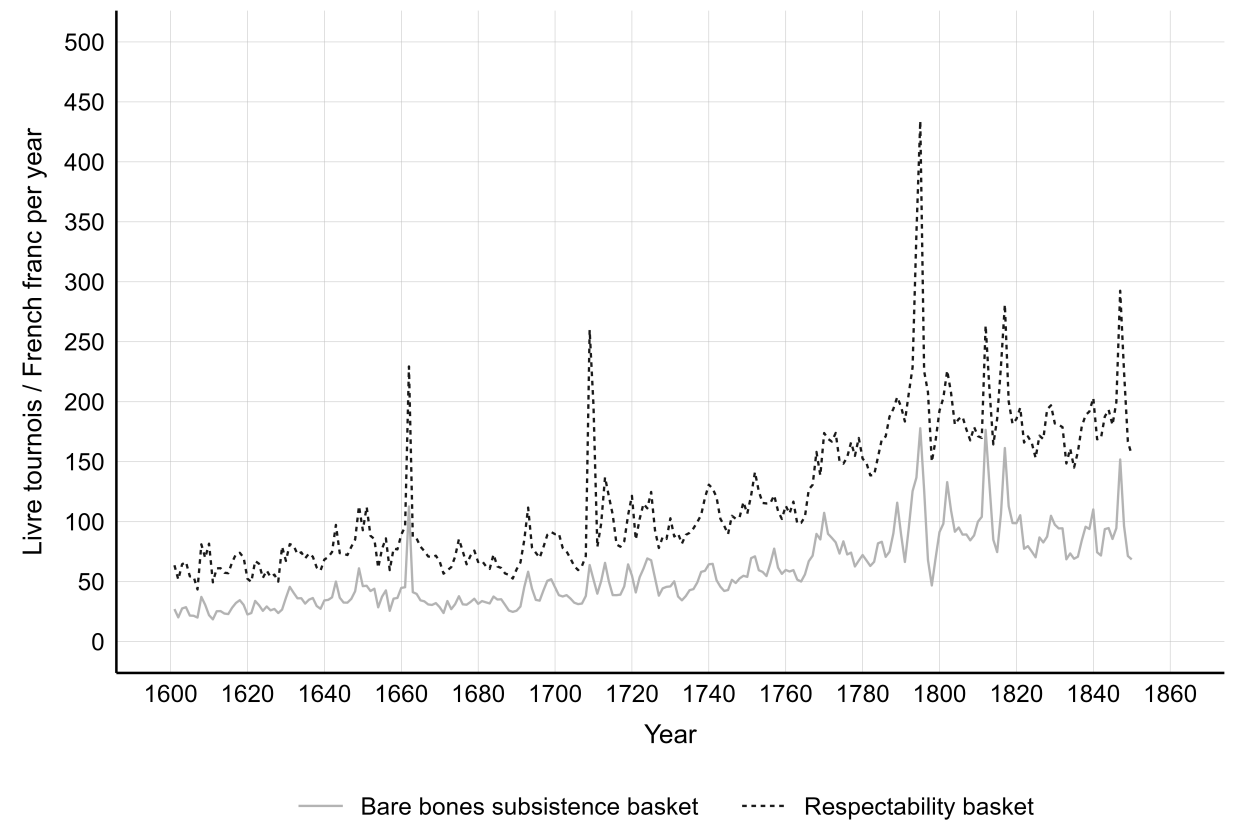

Sources: See Section 2.3 and Online Appendix Sections A.3 and A.4.

Figure A.13: The consumer price index

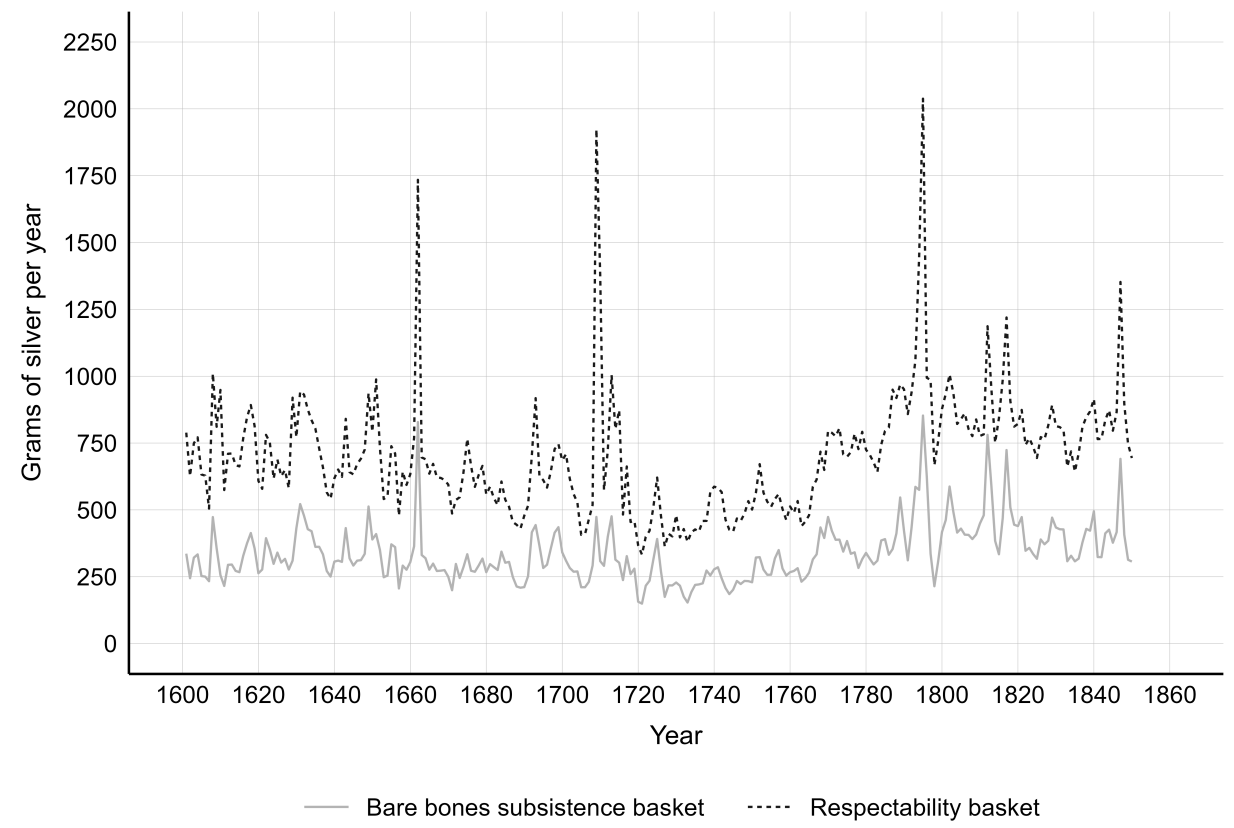

Sources: See Section 2.3 and Online Appendix Sections A.3 and A.4.

Figure A.14: The consumer price index in grams of silver in Normandy, 1601-1850 


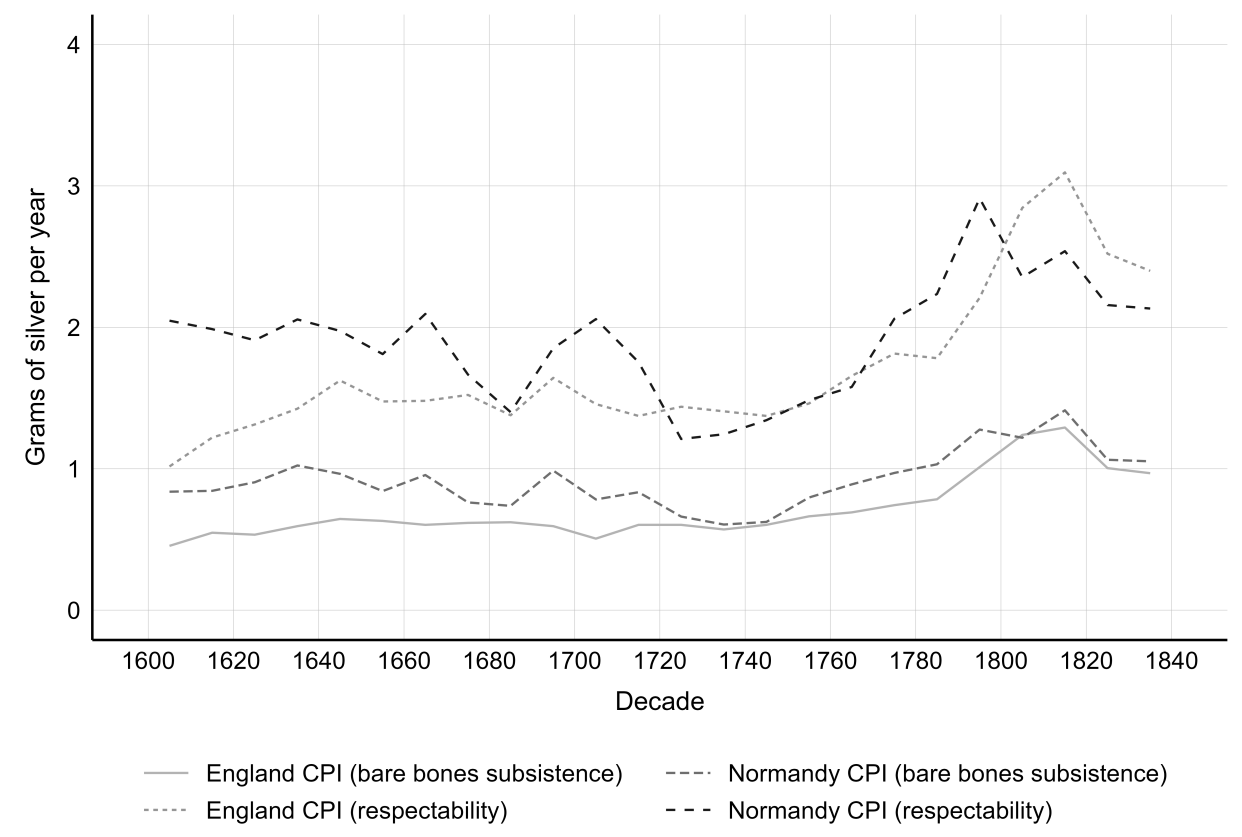

Sources: See Section 2.3 and Online Appendix Sections A.3 and A.4. Data for England are from Humphries and Weisdorf (2019, Online Appendix Tables A1 and A2).

Figure A.15: The consumer price index in England and Normandy, 1601-1850

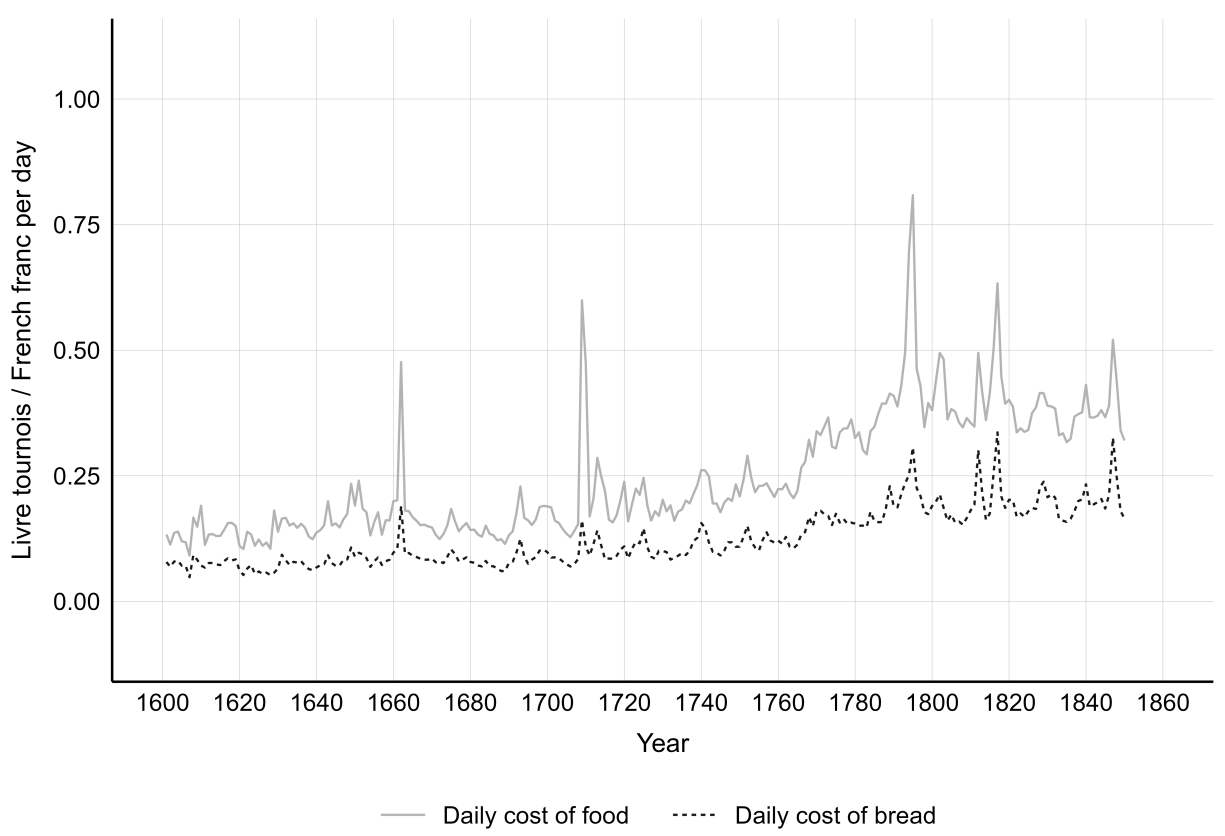

Notes: Bread prices are derived from wheat prices following Allen (2001, pp. 418-9). Sources: See Section 2.3 and Online Appendix Sections A.3 and A.4.

Figure A.16: The daily cost of food in a respectability basket in Normandy, 1601-1850 


\section{List of sources}

In this section, we give a detailed list of primary and secondary sources used to construct the price and wage series. We grouped primary sources by main types to ease the identification of raw materials used in the paper. For each group, we briefly describe of the type of information contains in the document.

\section{PRIMARY SOURCES}

\section{Administrative sources}

For the period 1601-1850, several administrative sources can be used to document market prices and wages. For the 18th century, we widely used the Mercuriales to collect information on prices. These archival documents contain, for all market towns, the statements made by official agents at the end of the market indicating the average price at which the main commodities, especially grain, were sold. On the other hand, the Apprécies are older sources which give the average price of the main commodities sold in all markets in a given geographical area, often at the Bailliage level, at different times of the year (Michaelmas, Easter, Christmas, St. John). To document regional prices disparities, we also relied on the Etats des prix des subdélégations that document the evolution of grain prices in the principal markets of a geographical area. For the revolutionary period, we used the Tableaux du Maximum which were established by the official agents to fix the prices of all commodities and wages in 1793 (Le Roux 1996). Finally, for the 19th century, we relied on the administrative records compiled at the departmental level which aggregated the market prices of the main towns and the mean wages for different occupations.

\section{Archives Nationales}

- G 7 71, Mémoire du prix des blés dans la généralité d'Alençon envoyé par l'Intendant.

- F 12 650, Mémoires des inspecteurs des Manufactures de Rouen.

- F 12 658A, Mémoires des inspecteurs des Manufactures de Rouen.

- F 14 4237, Rapport de Hérault, ingénieur des mines.

\section{Archives départementales du Calvados}

- 2B 1689/2, Apprécies du prix des grains de Bayeux.

- 3B 630, Bailliage de Falaise, Mémoire des apprécies de 1644 jusque es compris 1667.

- 3B 631, Bailliage de Falaise, Apprécies des grains, 1730-1765.

- 14B 1938, Apprécies des grains dans le ressort du bailliage de Caen.

- C 2342, Affaires militaires, magasins de grains. 
- C 2646, Affaires de l'intendance, commerce des grains.

- C 2712-2756, état des prix de la généralité de Caen.

- 856EDT 244, Falaise, Mercuriales, 1790-an V.

- 856EDT 275-278, Lisieux, Mercuriales, 1790-an V.

- 386EDT 219-225, Mercuriales de la halle de Falaise (1790-1818).

- 386EDT 244, Mercuriales de la halle de Falaise (1799-1811).

- F 1104, Apprécies (1692).

- F 1697, Registre de comptes et apprécies du blé à Cheux (1568-1789).

- F 4212, Apprécies des Bleds et autres denrées pour le Baillage de Mortain.

- F 5475, Apprécis du baillage de Thorigny (1754-1788).

- F 6560, Chartrier de Vaussieux, Apprécies du froment au greffe de Bayeux (16771713).

- 2L 222, Apprécies de la halle de Troarn.

- $1 Z$ 620, Sous-Préfecture de Bayeux, mercuriales (1828).

- $1 Z$ 842, Sous-préfecture de Bayeux, Prix moyen des journées d'ouvrier (an IX-an XI)

- $3 Z$ 267, Sous-préfecture de Falaise, Mercuriales (1801).

- 3Z 395, Sous-préfecture de Falaise, Prix de la journée de travail (1809).

\section{Archives départementales de 1'Eure}

- 6B 206, Registre des appréciations des grains pour le baillage de Breteuil.

- 9M 10, Salaires départementaux (1830-1847).

\section{Archives départementales de la Manche}

- 353 J 362, Registre des apprécies du greffe du baillage de Saint-Lô.

\section{Archives départementales de l'Orne}

- C 69, états des prix communs des bleds de la généralité d'Alençon (1753-1772).

- C 77, états des prix communs des bleds de la généralité d'Alençon (1775).

\section{Arch. dép. Seine-Maritime}

- C 2184, Dépenses liées à la construction d'une route (1789).

- C 2198, Détails des réparations et entretien de routes (1788).

- 6M 1196, Arrondissement d'Yvetot, Approvisionnement de l'armée. 
- 6M 1341-1348, Prix des combustibles et des denrées.

- 6M 1379, Mercuriales de Rouen (1816-1817).

\section{Private account books}

Below are listed all the private and individual account books used in this paper for wages and prices. These sources are very diverse and heterogeneous in nature, since they can be account books related to the operation of a feudal or agricultural estate indicating the weekly or daily wages paid to labourers, daily expense journals, books of servants' engagements or livres de raison (diaries).

\section{Archives départementales du Calvados}

- E 53, Comptes et dépenses du duc d'Harcourt (1724).

- E 62, Duché d'Harcourt, comptabilité

- E 66-67, Mémoire des dépenses du duc d'Harcourt relatif aux journées des ouvriers (1759).

- E 444, Comptes du duc d'Harcourt (1782).

- 2E 144, Papiers de Chrétien, mâitre mercier drapier à Caen (1647-1690).

- 2E 399, Hadibert du Manoir, livre de comptes domestiques, 1660-1704.

- 2E 844, Registre de la dépense du harnois, Cambremer (1751-1788).

- 386EDT 614, Livre de comptes et dépenses, Falaise (1759).

- F 1697, Seigneurie de Cairon et Bretteville-l'Orgueilleuse, Registre de comptes et de raisons.

- F 1699, Registre des fermiers et rentiers de la paroisse de Cairon (1745).

- F 2139, Chartrier de Pontécoulant, Journal de dépenses, 1768-1780.

- F 2140, Chartrier de Pontécoulant, Journal des recettes et dépenses, 1782-1785.

- F 3992, Comptabilité d'un marchand drapier de Caen.

- F 4154, Mémoire de travaux agricoles au domaine de Montécot (1796-an VII).

- F 4172, des Vaux de Lévaré, Comptes et dépenses domestiques (1758-1768), Livre des gages des domestiques de la maison Lévaré (1738-1770).

- F 5309, Fonds Le Gueult, carnet de comptes divers (1737-1771).

- F 5335, Des Longrais, comptabilité (1824-1841).

- F 5338, Comptabilité domestique et diverses dépenses (1808-1855).

- F 6436, Fonds Le Cavelier, Famille Azire, marchands drapier.

- F 6785, Registre comptable de la famille Trenchant-Le Cerf (1797-1820). 
- F 6957, Chartrier Texier de Hautefeuille, Mémoires de journées de travail et de livraison de fers à cheval (1736-1745), Registre de dépenses domestiques (1747-1758 et 1800-1801).

- F 7052-7066, Comptes, dépenses et mémoires de la Mine du Molay-Littry.

- F 7166, Registre comptable de Geffray des Portes (1766-1805).

- F 7319, Journal des dépenses de Jacques Riboult, curé de la paroisse d’Ussy.

- F 7797-7842, Chartrier de Barneville (alias Basseneville).

- 27F 18, Livre de comptes et livre d'engagement des domestiques.

- 37F 4, Fonds Vangeon, Maison de commerce Veuve Le Boyer.

- 1J 321, Comptes d'exploitation du château de Bénouville (1748-1753).

\section{Archives départementales de l'Orne}

- E 2239, Livre de comptes de la verrerie de la Puisaye.

\section{Archives départementales de la Seine-Maritime}

- D 555, Livre de la dépense de la Congrégation de Notre-Dame de Rouen, 1644-1651.

- J 1329, Mémoire des travaux faits par Jacques Fortier

\section{Société Historique de Lisieux}

- 1 F 811, Comptes du Château de Fumichon (1780-1781).

- 2 F A 18, Etat des journées faites par Moy Joachim Gerier Menuisier.

- 2 F A 202, Comptes de Pierre David.

- 2 F B 16, Compte de dépenses de l'évêché de Lisieux.

\section{Institutional account books}

Another important archival sources used in this paper are the books indicating the incomes and expenditures of several institutions (hospitals, bishoprics, universities, cathedrals, churches and parish assemblies). As for private account books, these sources are varied and heterogeneous. They can contain the daily expenses for commodities and wages, monthly records, or summaries of exceptional expenses related to renovation or construction works.

\section{Archives départementales du Calvados}

- D 114, Comptes de l’Université de Caen (1793).

- D 253-254, Comptes de l'Université de Caen (1688-1690).

- D 269, Comptes de l’Université de Caen (1663-1669). 
- D 278-283, Comptes de l'Université de Caen (1760-1769).

- D 320-322, Comptes de l’Université de Caen (1783).

- D 336, Comptes de l’Université de Caen (1771).

- D 346, Comptes de l’Université de Caen (1776).

- D 366, Comptes de l’Université de Caen (1695).

- 386EDT 644, Comptes de l'hôpital de Falaise (1800-1801).

- 6G 217, Comptes de dépenses de l'évêché de Bayeux (1753-1754).

- G 953, Travaux faits au château de Caen (1600-1617).

- H 64, Comptabilité et paiement des journaliers de l'abbaye d'Ardennes (1700-1713).

- H Supp. 177-182, Comptes de l'Hôpital de Lisieux (1745-1768).

- H Supp. 782-787, Comptes de dépenses de l’Hôpital de Bayeux (1716-1719).

- H Supp. 1141-1144, Comptes de dépenses de l’Hôpital de Bayeux (1672-1701).

- H Supp. 1209-1294, Comptes de dépenses de l’Hôpital de Bayeux (1701-1725).

- H Supp. 1430, Comptes de recettes et dépenses de l'Hôpital d'Orbec (1727-1728).

- H Supp. 1437-1444, Comptes de recettes et dépenses de l'Hôpital d'Orbec (17491757).

- H Supp. 1631, Comptes de recettes et dépenses de l'Hôpital d’Honfleur (1713).

- H Supp. 1639-1644, Comptes de recettes et dépenses de l'Hôpital d'Honfleur (17451751).

- H Supp. 1651-1665, Comptes de recettes et dépenses de l'Hôpital d'Honfleur (17591773).

\section{Archives départementales de 1'Eure}

- G 309, Comptes de la fabrique d'Amfreville (1673).

\section{Archives départementales de l'Orne}

- G 1299, Comptes de la fabrique d'Auguaise (1727).

- H 3585, Journal de la recette de l'abbaye d'Almenêches (1730).

- H 4197-4198, Comptes de l'abbaye d'Argentan (1623-1788).

- H 5550, état de la dépense de la communauté d'Essay (1790).

\section{Local newspapers}


At the end of the 18th century, local newspapers, such as the Journal de Rouen or Affiches, annonces et avis divers de la Basse-Normandie, started to report on a weekly basis the prices of grains sold at the local market. Unfortunately, they do not cover a long time period and only offer continuous time series for few years. All these newspapers are digitised and available online on the website of the departmental archives or on the Normannia website (www.normannia.info).

\section{Bibliothèque nationale de France $(\mathrm{BnF})$}

- Gazette du commerce (1763-1783). https:/ / gallica.bnf.fr/ark:/12148/cb32781047d/ date.

\section{Archives départementales du Calvados}

- Affiches, annonces et avis divers de la Basse-Normandie (1786-1792). http:// presselocaleancienne.bnf.fr/ark:/12148/cb326830540.

- Affiches, annonces et avis divers du département du Calvados (1801-1811). http: / / presselocaleancienne.bnf.fr/ark:/12148/cb42047070f.

- Journal politique et annonces judiciaires de Caen et du département de Calvados (1811-1829). http://presselocaleancienne.bnf.fr/ark:/12148/cb328006658.

- Le Haro, national normand. http:/ / http:/ / presselocaleancienne.bnf.fr/ark:/12148/ cb32785860s.

- Le Normand, journal politique, commercial et littéraire de l'arrondissement de Lisieux (1832-1870). http:/ / presselocaleancienne.bnf.fr/ark:/12148/cb344776890.

\section{Archives départementales de la Seine-Maritime}

- Journal de Rouen. http:/ / www.archivesdepartementales76.net/rechercher/archives-en-ligne/ journal-de-rouen.

\section{Archives départementales de l'Orne}

- Le journal d'Alençon et du département de l'Orne. http://presselocaleancienne. bnf.fr/ark:/12148/cb327968351.

- Le nouvelliste Alençonnais, journal du département de l'Orne. http:/ / presselocaleancienne. bnf.fr/ark:/12148/cb32826969b.

\section{Varia}

\section{Archives départementales de la Seine-Maritime}

- 7F 65, Notes de Pierre Dardel (salaires).

- 7F 90, Notes de Pierre Dardel (salaires). 


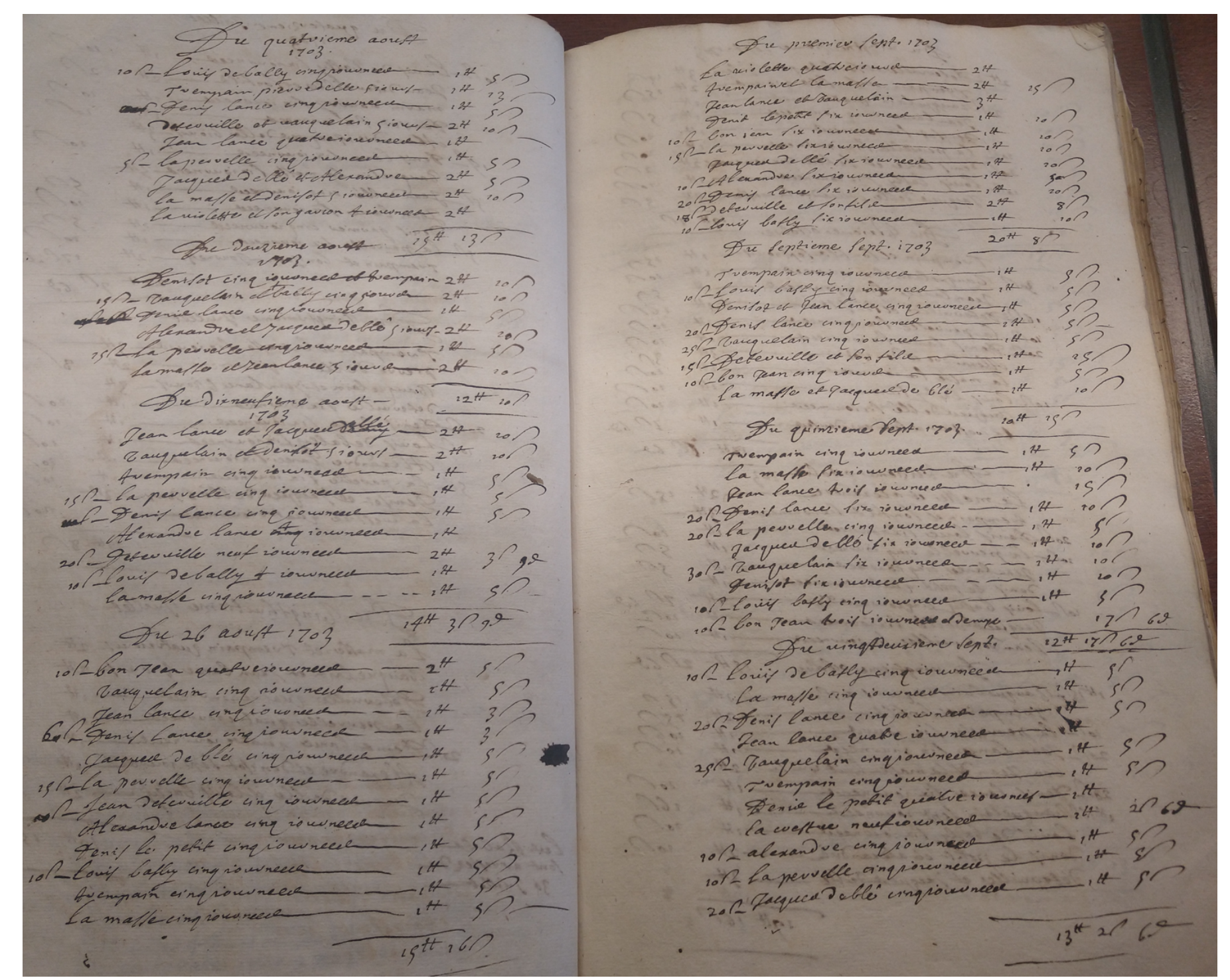

Sources: Arch. dép Calvados, H 64, Comptabilité et paiement des journaliers de l'abbaye d'Ardennes (1700-1713).

Figure A.17: Example of document used to build the database on wages 


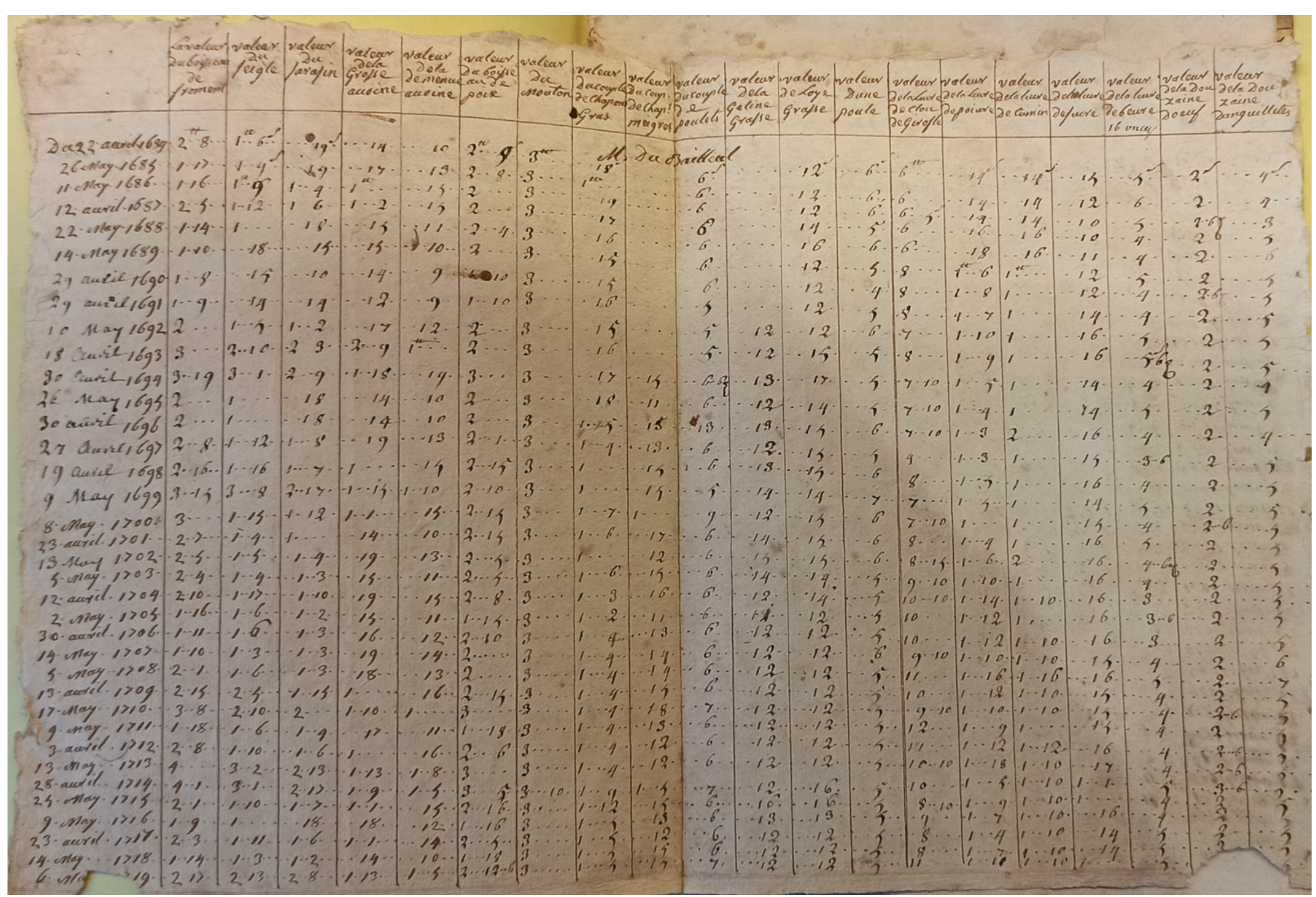

Sources: Arch. dép Calvados, F 4212, Apprécies des Bleds et autres denrées pour le Baillage de Mortain.

Figure A.18: Example of document used to build the database on prices 


\section{SECONDARY SOURCES}

'Abbaye de Saint-Martin-de-Monaye, ordre des prémontrés' (1834). Mémoires de la société des Antiquaires de Normandie 8.2, pp. 55-58.

'Agriculture' (1830). Annuaire du département du Calvados, pp. 137-1746.

'Agriculture' (1834). Annuaire des cinq départements de l'ancienne Normandie 1, pp. 339-387.

Archives statistiques du Ministère des travaux publics, de l'agriculture et du commerce (1837). Paris: Imprimerie Royale, p. 306.

Auffret, Marc (1968). 'L'industrie linière normande au XIXe siècle'. PhD thesis. Université de Caen, p. 181.

Auvray, Raymond (1840). 'Enquête industrielle sur l'exploitation des granites'. Annuaire des cinq départements de l'ancienne Normandie 6, pp. 280-300.

Avisseau-Roussat, Hélène (1964). 'L'Hôpital Saint-Antoine de la Charité de Pontorson (16441792)'. Revue du département de la Manche 6.23, pp. 113-200.

Barrey, Philippe (1976). 'L'arsenal du Havre pendant la Révolution (1789-1801)'. Recueil des publications de la Société havraise d'études diverses 3, pp. 277-308.

Base de données «Le désarmement havrais » (n.d.). URL: http:/ / desarmementshavrais.free.fr.

Base de données "Mémoires des Hommes » (n.d.). Ministère des Armées. URL: https: / / www. memoiredeshommes.sga.defense.gouv.fr.

Baudot, Marcel (1952). 'La crise alimentaire des années 1846 et 1847 dans le département de l'Eure'. Annales de Normandie 2.1, pp. 51-56. DOI: 10.3406/annor.1952.4219.

Becchia, Alain (2000). La draperie d'Elbeuf des origines à 1870. Rouen: Publications de l'Université de Rouen, p. 869.

Bénet, Armand (1891). Inventaire sommaire des archives départementales du Calvados, série $H$ supplément. Tome 1. Hôpitaux de Lisieux et de Bayeux. Caen: Henri Delesques, p. 398.

- (1900). Inventaire sommaire des archives départementales du Calvados, série H supplément. Tome 2. Hôpitaux de Honfleur, Orbec et Bois-Halbout. Caen: Henri Delesques, p. 343.

- (1905). Inventaire sommaire des archives départementales du Calvados, série E. Tome 1. Duché d'Harcourt. Caen: Henri Delesques, p. 356.

Bergasse, Alphonse (1852). Recherches sur la consommation de la viande et du poisson à Rouen depuis 1800. Rouen: Imprimerie Alfred Péron, p. 182.

Besnou, Aimé (1840). 'Rapport sur l'industrie de Villedieu'. Annuaire des cinq départements de la Normandie 6, pp. 175-197.

Biollay, Léon (1886). Les prix en 1790. Paris: Librairie Guillaumin, p. 508.

Birée, Patrick (2015). 'Les moulins hydrauliques à grains et les minoteries de l'alençonnais, XVII ${ }^{e}-X X^{e}$ siècles. De la lumière à l'ombre, quatre siècles d'évolution.' $\mathrm{PhD}$ thesis. Université de Caen-Normandie, p. 601.

Blanchard, Dom. (1915). 'L'abbaye de Saint-Étienne de Caen sous la Règle de Saint-Maur'. Bulletin de la Société des antiquaires de Normandie 30, pp. 1-339.

Bodinier, Bernard (2013). ‘Un journal paysan au XVIII ${ }^{\mathrm{e}}$ siècle. Le livre de recettes et dépenses de François Jacques Maret laboureur et vigneron à Bueil (Eure), de 1730 à 1761'. Histoire $\mathcal{E}$ Sociétés Rurales 40.2, pp. 97-154. DOI: 10.3917/hsr.040.0097. 
Bodinier, Bernard (2014). 'Un journal paysan au XVIII' siècle. Le livre de recettes et dépenses de François Jacques Maret laboureur et vigneron à Bueil (Eure), de 1730 à 1761'. Histoire $\mathcal{E}$ Sociétés Rurales 41.1, pp. 137-193. DOI: 10.3917/hsr.041.0137.

Bottin, Jacques (1983). Seigneurs et paysans dans l'ouest du Pays de Caux (1540-1650. Paris: Le Sycomore, p. 456.

Bouloiseau, Marc (1956). 'Aspects sociaux de la crise cotonnière dans les campagnes Rouennaises en 1788-1789'. In: Actes du 81e Congrès des Sociétés Savantes, Section d'histoire moderne et contemporaine (Rouen-Caen). Paris: Presses Universitaires de France, pp. 403-428.

Bourgin, Hubert and Georges Bourgin (1920). L'industrie sidérurgique en France au début de la Révolution. Paris: Imprimerie Nationale, p. 561.

Bourgne, A. (1915). 'Enquête sur la situation et les tendances actuelles de l'agriculture en France au cours du XIX ${ }^{\mathrm{e}}$ siècle et jusqu'à ce jour'. Recueil de la Société d'agriculture, sciences, arts et belles-lettres du département de l'Eure 7.2, pp. 16-57.

Bréard, Charles (1904). L'abbaye de Notre-Dame-de-Grestain de l'ordre de Saint-Benoit à l'ancien diocèse de Lisieux. Rouen: A. Lestringant, p. 435.

Caillard, Michel (1963). 'Recherches sur les soulèvements populaires en Basse-Normandie (1620-1640) et spécialement sur la révolte des Nu-pieds'. Cahier des Annales de Normandie 3, pp. 23-152. DOI: 10.3406/annor.1963.3630.

Caumont, Arcisse de (1840). 'Notes sur le prix du blé en Basse-Normandie à partir du XIII siècle'. Mémoires de la Société des Antiquaires de Normandie 12, pp. 418-420.

Chatel, Victor (1866). 'Déclaration, à l'Assemblée du clergé de France tenue en 1730, du curé de Vaucongrain, au sujet des dîmes par lui perçues'. Bulletin de la Société des antiquaires de Normandie 7.1, pp. 629-632.

Chaussat, Alain-Gilles (2017). 'Les population du Massif Armoricain au crible du sarrasin : Étude d'un marqueur culturel du bocage normand (XVI $-X X^{\mathrm{e}}$ siècle)'. PhD Thesis. Université de Caen-Normadie, p. 850.

Cilleuls, Alfred des (1887). 'Le prix de la vie en France du XVIe siècle à 1789'. Revue générale d'administration 2, pp. 24-39.

Cobb, Richard Charles (1954). 'Journées et salaires au Havre en l'an III'. Annales de Normandie 4.1, pp. 73-76.

Cochard, Nicolas (2016). Les marins du Havre: Gens de mer et société urbaine au XIX siècle. Rennes: Presses Universitaires de Rennes, p. 338. DOI: 10.4000/books.pur.46978.

Collet, Louis (1938). 'Les Aubry, seigneurs de Basseneville (Calvados) au XVIII siècle'. Bulletin de la société des antiquaires de Nomandie 46, pp. 316-332.

Comité régional d'histoire de la Révolution française (1988). La Révolution en Haute-Normandie (1789-1802). Rouen: Éditions du P'tit Normand, p. 464.

Dardel, Pierre (1934). 'Statuts des boulangers et barème du prix du pain à Lillebonne et à Bolbec vers 1461'. Bulletin de la société libre d'émulation de la Seine-Inférieure Année 1933, pp. 315-334. DOI: https:/ / gallica.bnf.fr/ark:/12148/bpt6k6561000c.

- (1963). Navires et marchandises dans les ports de Rouen et du au XVIII' siècle. Paris: S.E.V.P.E.N., p. 788. 
Darpentigny, G. (1905). 'Les forges de Putanges (suite et fin)'. Bulletin de la Société Historique et archéologique de l'Orne 24.3, pp. 517-562.

Delalonde du Thil, M. (1853). 'Moyens de porter remède à l'exhaussement du prix de la viande en détail'. Bulletin de la Société libre d'émulation de Rouen Années 1852-1853, pp. 106-113.

Delobette, Édouard (2005). 'Ces Messieurs du Havre. Négociants, commissionnaires et armateurs de 1680 à 1830'. PhD Thesis. Université de Caen-Normandie, p. 2547.

Deschamps de Vadeville (1877). 'Tableaux des apprécies de différentes denrées vendues au marché de Coutances de 1684 à 1778'. Mémoires de la Société académique du Cotentin : archéologie, belles-lettres, sciences et beaux-arts 2, pp. 225-247.

Désert, Gabriel (1977). 'Les archives hospitalières : source d'histoire économique et sociale'. Cahier des Annales de Normandie 10, pp. 3-252. DOI: 10.3406/annor.1977.3823.

- (1994). 'Réflexions sur les industries rurales en Basse-Normandie du Premier au Second Empire'. Annales de Normandie 44.3-4, pp. 239-254. DOI: 10.3406/annor.1994.4627.

- (2007). Les Paysans du Calvados, 1815-1895. Caen: Centre de Recherche d'Histoire Quantitative, p. 864.

Despierres, Gérasime (1886). Histoire du point d'Alençon depuis son origine jusqu'à nos jours. Paris: H. Laurens, p. 276.

Dubois, M. G. (1934). 'La gestion économique de la communauté des Nouvelles-Catholiques aux XVII et XVIII ${ }^{\mathrm{e}}$ siècle'. Bulletin de la Société libre d'émulation du commerce et de l'industrie de la Seine-Inférieure Année 1933, pp. 265-280.

Dubosc, François (1866). Inventaire sommaire des archives du département de la Manche, série $H$. Tome 1. Abbayes de Aunay, Blanchelande et Cerisy. Saint-Lô: A. Jacqueline, p. 682.

Dubuc, André (1963). 'L'appréciation des redevance en nature dans le baillage principal de Rouen (1694-1790)'. In: Actes du 87e Congrès national des sociétés savantes (Poitiers, 1962). Section d'histoire moderne et contemporaine. Paris: Imprimerie Nationale, pp. 813-847.

Dujardin, Laurent (1995). 'Extraction et vente de la pierre dans une carrière de Caen de la deuxième moitié du XVIII ${ }^{\mathrm{e}}$ siècle. Étude d'un registre d'exploitation'. Annales de Normandie 45.2, pp. 115-193. DOI: 10.3406/annor.1995.4650.

Dujardin, M. (1842). 'Industrie, commerce, navigation'. Annuaire des cinq départements de l'ancienne Normandie 9, pp. 274-374.

Duval, Louis (1883). Documents pour servir à l'histoire du pont d'Alençon. Alençon: E. Renaut-deBoise, p. 108.

- (1890). 'Notes historiques sur la ville de Sées au XVIII ${ }^{\mathrm{e}}$ siècle'. Annuaire des cinq départements de la Normandie 56, pp. 141-183.

- (1891). Inventaire sommaire des archives départementales de l'Orne, série H. Tome 1. Alençon: E. Renaut de Broise, p. 378.

- (1894). Inventaire sommaire des archives départementales de l'Orne, série H. Tome 2. Alençon: E. Renaut de Broise, p. 267.

- (1896). Essai historique sur le cidre et le poiré. Paris: Octave Doin, p. 116.

- (1899). Inventaire sommaire des archives départementales de l'Orne, série H. Tome 3. Alençon: E. Renaut de Broise, p. 331. 
Duval, Louis (1903). Inventaire sommaire des archives départementales de l'Orne, série H. Tome 4. Alençon: Impr. Herpin, p. 343.

- (1908a). 'Un gentilhomme cutlivateur au XVIII siècle : Samuel de Frotté de La Rimblière. Étude biographique et économique'. Bulletin de la société historique et archéologique de l'Orne 27, pp. 197-232.

- (1908b). Un gentilhomme cutlivateur au XVIII siècle : Samuel de Frotté de La Rimblière. Son livre de comptes. Alençon: Imprimerie Alençonnaise, p. 80.

Duval, Marcel (1963). 'L'élection de Carentan du milieu du XVII ${ }^{\mathrm{e}}$ au milieu du XVIII ${ }^{\mathrm{e}}$. Étude d'Histoire sociale'. Annales de Normandie 3, pp. 155-271. DOI: 10.3406/annor.1963.3639.

El Kordi, Mohamed (1970). Bayeux aux XVII et XVIII siècles. Contribution à l'histoire urbaine de la France. Paris: E.P.H.E., VIe section Sciences Économiques et Sociales, p. 372.

'Enquête agricole à Goderville' (1851). Annuaire des cinq départements de l'ancienne Normandie 17, pp. 323-357.

'Enquête industrielle' (1845). Annuaire des cinq départements de l'ancienne Normandie 11, pp. 247272.

'Enquête industrielle' (1847). Annuaire des cinq départements de l'ancienne Normandie 13, pp. 272277.

'Enquête morale commerciale et industrielle à Bolbec' (1851). Annuaire des cinq départements de l'ancienne Normandie 17, pp. 261-302.

Évrard, Fernand (1947). 'Les ouvriers du textile dans la région rouennaise (1789-1802)'. Annales historiques de la Révolution française 19.1008, pp. 333-352.

Faisant, Étienne (2013). 'L'architecture à Caen du règne de Charles VIII au début du règne de Louis XIII'. PhD Thesis. Université de Paris 4.

Ferrière, Hector de la (1855). Histoire de Flers, ses seigneurs, son industrie. Paris: Dumoulin, p. 312.

Ferrière-Percy, Henri de la (1859). Le journal de la comtesse de Sanzay. Intérieur d'un château normand au XVI siècle. Paris: Auguste Aubry, p. 189.

Follain, Antoine (1991). 'Une confrérie normande du XVI e au XVIII siècle : la charité de Montfort-sur-Risle'. Études Normandes 40.2, pp. 41-52. DOI: 10.3406/etnor.1991.1983.

Follain, M. (1840). 'Mémoire sur le commerce et l'industrie de Granville'. Annuaire des cinq départements de l'ancienne Normandie 6, pp. 158-174.

Galeron, Frédérique, Jules Desnoyers and Alphonse de Brébisson (1826). Statistique de l'arrondissement de Falaise. Tome 1. Falaise: Brée l'aîné, p. 580.

Gardier (1864). 'Rapport au nom de la commission d'enquête industrielle sur les progrès de l'industrie à Bernay depuis 1848'. Annuaire des cinq départements de la Normandie 30, pp. 292315.

Garnier, Bernard (2004). 'Aspects matériels de la vie à Pontécoulant au XVIII siècle'. Annales de Normandie 54.2-3, pp. 115-166. DOI: 10.3406/annor.2004.1484.

Glanville, Léonce de (1891). Histoire du prieuré de Saint-Lò de Rouen : ses prieurs, ses privilèges, ses revenus. Tome II. Rouen: Imprimerie Espérance Cagniard, p. 516.

Gosselin, Édouard (1869). 'Du prix des denrées comparé au salaire journalier des artisans de 1489 à 1789'. Revue de la Normandie 8.1, pp. 115-129. 
Granges, Edmond de (1855). Encyclopédie du commerçant. Dictionnaire du commerce et des marchandises contenant tout ce qui concerne le commerce de terre et de mer. Tome 1. Librairie L. Hachette, p. 996.

Gullickson, Gay L. (2002). The Spinners and Weavers of Auffay: Rural Industry and the Sexual Division of Labor in a French village. Cambridge: Cambridge University Press, p. 256.

Hauser, Henri (1936). Recherches et documents sur l'histoire des prix en France de 1500 à 1800. Paris: Impr. Les Presses modernes, p. 525.

'Industrie' (1843). Annuaire des cinq départements de l'ancienne Normandie 10, pp. 351-359.

Jambu, Jérôme (2013). Tant d'or que d'argent : la monnaie en Basse Normandie à l'époque moderne (XVI $I^{e}$ XVIII ${ }^{e}$ siècle). Rennes: Presses Universitaires de Rennes, p. 640.

Jigan, Claude (1997). 'Faïenceries rouennaises au XVIII ${ }^{\mathrm{e}}$ siècle'. Annales de Normandie 47.3, pp. 227-242. DOI: 10.3406/annor.1997.4791.

Jouanne, René (1931). 'Études et notes d'histoire économique. La Basse Normandie au temps de Jeanne d'Arc et d'Ambroise de Loré'. Bulletin de la Société historique et archéologique de l'Orne 50.4, pp. 1-32.

- (1932). 'La taxation à Sées en 1693, et 1711-1715'. Bulletin de la Société historique et archéologique de l'Orne 51.4, pp. 59-64.

La Sicotière, Léon de (1894). 'La société royale d'agriculture de la généralité d'Alençon (17621790)'. Bulletin de la Société historique et archéologique de l'Orne 13.4, pp. 488-509.

Labrousse, Ernest (1933). Esquisse du mouvement des prix et des revenus en France au XVIII siècle. Paris: Dalloz, p. 306.

Langlois, Eustache-Hyacinthe (1823). Notice sur l'incendie de la cathédrale de Rouen occasioné par la foudre le 15 septembre 1822. Rouen: Impr. de F. Baudry, p. 180.

Le Cacheux, Paul (1845). Essai historique sur l'Hôtel-Dieu de Coutances, l'Hôpital Général et les Augustines hospitalières depuis l'origine jusqu'à la Révolution. Paris: Alphonse Picard, p. 315.

- (1895). 'Une visite à l'hôtel-Dieu de Coutances'. Revue catholique de Normandie 5, pp. 273306.

Le Hardy, M. G. (1897). 'Étude sur la baronnie et l'abbaye d'Aunay-sur-Odon'. Bulletin de la Société des antiquaires de Normandie 19, pp. 1-438.

Le Parquier, Eugène (1933). 'Ouvriers et Patrons dans la seconde moitié du XVIII siècle'. Bulletin de la Société libre d'émulation du commerce et de l'industrie de la Seine-Inférieure Année 1932, pp. 111-200.

Le Teneur, René (1970). Carentan à travers les siècles. Histoire d'une petite ville normande. Coutances: Éditions O.C.E.P., p. 475.

Lecointre-Dupont, Gabriel (1837). ‘Rapport sur le commerce et l'industrie du département de l'Orne'. Annuaire des cinq départements de l'ancienne Normandie 3, pp. 294-330.

Lécureur, Bertrand (1997). 'L'hôpital du Havre, de la fin du XVII ${ }^{\mathrm{e}}$ au début du XX' siècle, miroir des relations commerciales et humaines entre une ville et son arrière-pays)'. Master Thesis. Université de Caen.

Lefebvre, Georges (1926). 'Les mines de Littry sous l'ancien régime et pendant les premières années de la Révolution (1744-1793)'. Annales historiques de la Révolution française 3.13, pp. 16-36. 
Lefebvre, Georges (1965). 'Cherbourg à la fin de l'Ancien Régime et au début de la Révolution'. Cahier des Annales de Normandie 4, pp. 3-296. DOI: 10.3406/annor.1965.4126.

Lefèvre, Léon-Paul (1908). Yvetot pendant la Révolution (1788-1815). Yvetot: Léon Lachèvre Imprimeur, p. 260.

Lefort, André (1886). Salaires et revenus dans la généralité de Rouen au XVIII siècle comparés avec les dépenses de l'alimentation, du logement, du chauffage et de l'éclairage. Rouen: Impr. E. Cagniard, p. 67.

Lemarchand, Guy (1989). La fin du féodalisme dans le pays de Caux. Conjoncture économique et démographique et structure sociale dans une région de grande culture : de la crise du XVIIe siècle à la stabilisation de la Révolution (1640-1795). Paris: Éditions du CTHS, p. 661.

Lepetit, Henriette (1987). Sur les traces de la manufacture des glaces : Tourlaville (1667-1830). Condé-sur-Noireau: Imprimerie Corlet, p. 191.

Leroy, Charles (1929). Paysans normands au XVIII siècle. Tome 2. Rouen: Imprimerie A. Lestringant, p. 462.

- (1930). Notes sur la seigneurie et la paroisse de Venesville au Pays de Caux. Rouen: Imprimerie A. Lestringant, p. 91.

- (1932a). 'Quelques salaires et quelques prix au Pays de Caux au XVII et XVIII ${ }^{\mathrm{e}}$ siècles'. Bulletin de la Société libre d'émulation du commerce et de l'industrie de la Seine-Inférieure Année 1931, pp. 151-158.

- (1933). Notes sur la seigneurie de la paroisse de Malleville-les-Gres au Pays de Caux. Rouen: Imprimerie Lestringant, p. 51.

- (1934). Notes sur une exploitation agricole en Normandie, dans le Roumois au XVIIIème siècle. Rouen: Imprimerie A. Lestringant, p. 178.

- (1936). 'Dans une ferme du Roumois sous l'Empire et la Restauration (1804-1822)'. Annuaire des cinq départements de la Normandie 103, pp. 34-63.

Leroy, Henry (1932b). 'Le livre de raison de François Tessier de la Roche'. Bulletin de la Société libre d'émulation du commerce et de l'industrie de la Seine-Inférieure Année 1931, pp. 159-174.

Longuemare, Pierre de (1909). 'Monographie de la commune de Vendes'. Annuaire des cinq départements de la Normandie 76.590, pp. 1-240.

Macé, C. (1890). 'Joué-du-Bois. Paroisse, fiefs, commune du XVe siècle à la fin du XVIII ${ }^{\mathrm{e}}$ siècle'. Bulletin de la Société Historique et archéologique de l'Orne 9, pp. 285-327.

Malicorne, J. (1907). Recherches historiques sur l'agriculture dans le Pays de Bray, troisième partie (1707-1789). Rouen: Impr. L. Gy, p. 157.

Mancel, Georges (1848). Journal d'un bourgeois de Caen (1652-1733). Caen: Charles Woinez, p. 433.

Maneuvrier-Hervieu, Paul (2017). 'La Révolution française vue et vécue par un villageois du Pays de Caux'. Histoire E Sociétés Rurales 47.1, pp. 137-180. DOI: 10.3917/hsr.047.0137.

Martin, Alphonse (1895). 'Questions agricoles'. Recueil des publications de la Société havraise d'études diverses 62.2, pp. 171-208.

Masson de Saint-Amand, Armand (1805). Mémoire statistique du département de l'Eure. Paris: Imprimerie Nationale, p. 140. 
Mouchel-Vallon, Patrice (2017). 'Croquants, rebelles et ligueurs en Cotentin à la fin du XVI siècle. La réécriture politique d'une révolte et de ses composantes : prosopographie de l'émeute, du saccage et du meurtre'. PhD Thesis. Université de Caen, p. 1012.

Navel, H. (1930). 'Monographie de Feuguerolles-sur-Orne (Calvados) des origines à la Révolution'. Bulletin de la Société des Antiquaires de Normandie 38, pp. 141-460.

Nicolle, Paul (1923). 'Histoire de Vire pendant la Révolution (1789-1800)'. PhD Thesis. Université de Caen, p. 718.

'Notice sur l'état et les progrès des arrondissements de Lisieux' (1837). Annuaire des cinq départements de l'ancienne Normandie 4, pp. 85-130.

Olivier, M. (1840). 'Rapport sur le commerce et l'industrie du canton d'Avranches'. Annuaire des cinq départements de l'ancienne Normandie 6, pp. 197-201.

Perrot, Jean-Claude (1975). Genèse d'une ville moderne : Caen au XVIII siècle. 2 vols. Paris: Mouton, p. 1157.

Plaisse, André (1961). La Baronnie du Neubourg. Essai d'histoire agraire, économique et sociale. Paris: Presses Universitaires de France, p. 760.

Poncet, Fabrice (2015). ‘Plus de beurre que de pain ? : la spécialisation agricole dans le Plain et le Bessin (XV'-XIX'e siècles)'. PhD Thesis. Université de Caen-Normandie, p. 818.

Pottier, André (1870). Histoire de la faïence de Rouen. Rouen: Auguste Le Brument, p. 420.

Poussier, Alfred (1910). 'Extrait d'un manuscrit de J-B. Gabriel Le Chandelier. Rouen (17911794)'. Bulletin de la Société libre d'émulation du commerce et de l'industrie de la Seine-Inférieure Année 1909, pp. 283-368.

Primois, Georges (1926). 'Notes sur la grosse forge du Pont-Oeuvre et sur le fourneau de SaintEvroult'. Bulletin de la Société Historique et Archéologique de l'Orne 45.2-3, pp. 165-245.

Quenault, Léopold (1877). 'L'Hôtel-Dieu de Coutances'. Mémoires de la société académique du Cotentin 2, pp. 1-22.

'Renseignements statistiques sur la consommation de la viande' (1835). Annuaire du département de la Manche 7, pp. 72-82.

Reybaud, Louis (1863). Le coton son régime, ses problèmes, son influence en Europe. Paris: Michel Lévy, p. 471.

Richard, Guy (1969). 'Les forges normandes en 1811'. Revue d'histoire des mines et de la métallurgie 1.2 , pp. 151-232.

Robillard de Beaurepaire, Charles de (1868). Inventaire sommaire des archives départementales de la Seine-Inférieure, série G. Tome 1. Paris: Imprimerie De Paul Dupont, p. 518.

- (1874). Inventaire sommaire des archives départementales de la Seine-Inférieure, série G. Tome 2. Paris: Imprimerie De Paul Dupont, p. 511.

- (1881). Inventaire sommaire des archives départementales de la Seine-Inférieure, série G. Tome 3. Paris: Imprimerie De Paul Dupont, p. 506.

- (1887). Inventaire sommaire des archives départementales de la Seine-Inférieure, série G. Tome 4. Paris: Imprimerie De Paul Dupont, p. 534.

- (1889). Renseignements statistiques sur l'état de l'agriculture vers 1789. Rouen: Imprimerie Espérance Cagniard, p. 113. 
Robillard de Beaurepaire, Charles de (1892). Inventaire sommaire des archives départementales de la Seine-Inférieure, série G. Tome 5. Rouen: Imprimerie Julien Lecerf, p. 503.

- (1896). Inventaire sommaire des archives départementales de la Seine-Inférieure, série G. Tome 6. Rouen: Imprimerie Julien Lecerf, p. 494.

- (1900). Inventaire sommaire des archives départementales de la Seine-Inférieure, série G. Tome 7. Rouen: Imprimerie Julien Lecerf, p. 494.

- (1903). 'Notice sur la Chartreuse de Saint-Julien composée d'après les comptes de cette communauté'. Précis analytique des travaux de l'Académie des sciences, belles-lettres et arts de Rouen Année 1902-1903, pp. 337-367.

- (1909). Derniers mélanges historiques et archéologiques concernant le département de la SeineInférieure et plus spécialement la ville de Rouen. Rouen: Imprimerie de L. Gy, p. 347.

- (1939). 'Situation du clergé de la catéhdrale et de la ville d'Avranches à la fin du XVIII siècle'. Bulletin de la société Libre d'émulation de la Seine-Inférieure Année 1938, pp. 17-31.

Roquelet, Alain (1981). ' "Rapports des grains de la halle d'Ellebeuf » ou prix des différents céréales à la halle d'Elbeuf (1630-1658)'. Annales de Normandie 31.1, pp. 21-36. DOI: 10 . 3406/annor.1981.5409.

Roussel (1878). 'Mémoire de M. Roussel sur l'industrie des tissus en lin, chanvre et coton du pays de Caux, depuis plusieurs siècles jusqu'à nos jours'. Annuaire des cinq départements de la Normandie 45, pp. 388-245.

'Salaire des ouvriers' (1837). Annuaire du département de la Manche 9, pp. 92-94.

Sales, A. (1885). 'Le collège de Ceaucé vers 1684'. Bulletin de la société historique et archéologique de l'Orne 4, pp. 1-40.

Sion, Jules (1909). Les paysans de la Normandie orientale. Pays de Caux, Bray, Vexin normand, Vallée de la Seine. Étude géographique. Paris: Armand Colin, p. 288.

Surville, A. (1912). 'L'abbaye de Belle-Étoile'. Bulletin de la Société historique et archéologique de l'Orne 31.1, pp. 113-140.

Tableau de la viande fraiche et salée, poisson sec et salé avec les prix en 1790, augmentés du tiers (1794). Paris: Imprimerie de Belin, p. 119.

Tableau des bois à brûler, avec les prix en 1790, augmentés d'un vingtième (1794). Paris: Imprimerie de Levieil, p. 67.

Tableau des boissons, avec les prix en 1790, augmentés du tiers (1794). Paris: Imprimerie de Volland, p. 74.

Tableau des charbons de bois, avec les prix en 1790, augmentés du vingtième (1794). Paris: Réfugiés Liégeois, p. 56.

Tableau des légumes secs, avec les prix en 1790, augmentés du tiers (1794). Paris: Imprimerie de Plassan, p. 83.

Tableau du maximum fixé en exécution de la Loi du 11 Brumaire, an 2. Épiceries et drogueries (1794). Paris: Imprimerie Nationale Exécutive du Louvre, p. 107.

Vaillant de la Fieffe, Olivier le (1873). Les verreries de la Normandie, les gentilshommes $\mathcal{E}$ artistes verriers normands. Rouen: C. Lanctin, p. 552. 


\section{Online Appendix References}

Allen, Robert C. (2001). 'The Great Divergence in European Wages and Prices from the Middle Ages to the First World War'. Explorations in Economic History 38.4, pp. 41-47. DOI: 10.1006/ exeh.2001.0775.

Désert, Gabriel (1977). 'Les archives hospitalières : source d'histoire économique et sociale'. Cahier des Annales de Normandie 10, pp. 3-252. DOI: 10.3406/annor.1977.3823.

Dewald, Jonathan (1987). Pont-Saint-Pierre, 1398-1789. Lordship, Community, and Capitalism in Early Moder France. Berkeley: University of California Press, p. 326.

Durand, M. (1850). 'Rapport général sur l'enquête agricole et industrielle qui a été faite dans le département du Calvados'. Annuaire des cinq départements de la Normandie 16, pp. 118-130.

Garnier, Bernard (2004). 'Aspects matériels de la vie à Pontécoulant au XVIII' siècle'. Annales de Normandie 54.2-3, pp. 115-166. DOI: 10.3406/annor.2004.1484.

Humphries, Jane (2013). 'The Lure of Aggregates and the Pitfalls of the Patriarchal Perspective: A Critique of the High Wage Eeconomy Interpretation of the British industrial Revolution'. The Economic History Review 66.3, pp. 693-714. DOI: 10.1111/j.1468-0289.2012.00663.x.

Humphries, Jane and Jacob Weisdorf (2019). 'Unreal Wages? Real Income and Economic Growth in England, 1260-1850'. The Economic Journal 129, pp. 2867-2887. DOI: 10.1093 / ej/uez017.

Le Hardy, M. G. (1897). 'Étude sur la baronnie et l'abbaye d'Aunay-sur-Odon'. Bulletin de la Société des antiquaires de Normandie 19, pp. 1-438.

Le Roux, Thomas (1996). Le Commerce intérieur de la France à la fin du XVIII siècle. Les contrastes économiques régionaux de l'espace français à travers les archives du Maximum. Paris: Nathan, p. 315. DOI: $10.3917 /$ nath.lerou.1996.01.

Lemarchand, Guy (1989). La fin du féodalisme dans le pays de Caux. Conjoncture économique et démographique et structure sociale dans une région de grande culture : de la crise du XVII siècle à la stabilisation de la Révolution (1640-1795). Paris: Éditions du CTHS, p. 661.

Masson de Saint-Amand, Armand (1805). Mémoire statistique du département de l'Eure. Paris: Imprimerie Nationale, p. 140.

Morineau, Michel (1972). 'Budgets populaires en France au XVIII siècle'. Revue d'histoire économique et sociale 50.2, pp. 203-237.

Pelletier, Jean le (1701). Mémoire pour le Rétablissement du Commerce en France. Rouen: s.n., p. 131.

Perrot, Jean-Claude (1975). Genèse d'une ville moderne : Caen au XVIII siècle. 2 vols. Paris: Mouton, p. 1157.

Ridolfi, Leonardo (2019). 'Six Centuries of Real Wages in France from Louis IX to Napoleon III: 1250-1860'. The Journal of Economic History 79.3, pp. 1-39. DOI: 10.1017/S0022050719000354.

Wailly, Natalis de (1857). Mémoire sur les variations de la livre tournois depuis le règne de saint Louis jusqu'à l'établissement de la monnaie décimale. Paris: Impr. Impériale, p. 251. 